\title{
HEINONLINE
}

Citation: 112 Yale L.J. 1473 2002-2003

Content downloaded/printed from

HeinOnline (http://heinonline.org)

Tue Jul 24 11:30:17 2012

-- Your use of this HeinOnline PDF indicates your acceptance of HeinOnline's Terms and Conditions of the license agreement available at http://heinonline.org/HOL/License

-- The search text of this PDF is generated from uncorrected OCR text.

-- To obtain permission to use this article beyond the scope of your HeinOnline license, please use:

https://www.copyright.com/ccc/basicSearch.do?

\&operation $=$ go\&search Type $=0$

\&lastSearch $=$ simple\&all $=0$ \& \& titleOrStdNo $=0044-0094$

Retrieved from DiscoverArchive,

Vanderbilt University's Institutional Repository

This work was originally published in

112 Yale L.J. 1473 2002-2003 


\title{
Essay
}

\section{The Secret History of Race in the United States}

\author{
Daniel J. Sharfstein ${ }^{\dagger}$
}

\section{INTRODUCTION}

In the beginning, there was a man named Looney. George Looney's world was Buchanan County, Virginia, a pocket of Appalachian hills and hollows that juts into Kentucky and West Virginia. In 1911, his place in this world was secure. Where lumber was the only industry in town, ${ }^{1}$ Looney owned a mill and a store. He had a thriving family. His home was near Looney's Creek.

† Law Clerk, Hon. Rya W. Zobel, U.S. District Court for the District of Massachusetts. A.B. 1994, Harvard College; J.D. 2000, Yale Law School. I would like to thank Evan Criddle, Robert W. Gordon, Ariela Gross, Matthew Lindsay, Ann-Marie Mikkelsen, Joshua Sharfstein, Brad Snyder, and John Tehranian for being wonderful readers, editors, and teachers. Completion of this Essay would not have been possible without the encouragement and support of Judge Zobel, Judge Dorothy W. Nelson, and my brilliant colleagues at Strumwasser \& Woocher LLP, Santa Monica, California. Special thanks also go to Steven Biel, Lawrence Buell, Henry Louis Gates, Jr., Jeffrey Melnick, Daniel Morris, Joseph Pearce, Thomas J. Siegel, and Werner Sollors for inspiration and instruction that continue to guide me.

1. The forests of Buchanan County were being cleared rapidly in the first decades of the twentieth century. By 1918 , only 1.3 percent of the county was untouched. Another 39.2 percent was classified as "virgin without poplar," and 41.3 percent had been entirely cutover. W.G. SCHWAB, THE FORESTS OF BUCHANAN COUNTY 7, 10 (1918). Within two decades, the local economy centered around mining the county's twelve billion tons of coal. See R.L. HUMBERT, INDUSTRIAL SURVEY: BUCHANAN COUNTY, VIRGINIA 27 (1930). In 1911, coal already dominated the economies of the surrounding counties. See RONALD D. ELLER, MINERS, MILlHANDS, AND MOUNTAINEERS: INDUSTRIALIZATION OF THE APPALACHIAN SOUTH, 18801930 , at 132-50 (1982) (describing the "phenomenal growth" of coal mining in Kentucky, Tennessee, Virginia, and West Virginia). 
But Looney's world was changing. Outsiders were moving to Appalachia to chop, saw, dynamite, and chisel the countryside. ${ }^{2}$ Among them were black people, never a common sight in Buchanan, "one of the whitest counties, not only in Virginia, but in the entire South." "The locals proved hostile to the newcomers. Although southwestern Virginia had an extremely small African-American population, more lynchings occurred there between 1880 and 1930 than in any other part of the state. ${ }^{4}$ The violence was most common in the more industrialized counties immediately to the east. Even so, in early 1893, after mobs lynched five blacks in neighboring Tazewell, vigilantes and rioters rode through Buchanan, declaring it "altogether a white county.",

About five years after the mob violence in Buchanan, a young man named George Spencer crossed the Kentucky line into Virginia. Over the next decade, he married a local woman, had six children, and settled near the Looneys. Spencer, a farmer, worked for Looney at times, and the families often ate together, stayed over at each other's houses, and sent their children to the same schools. ${ }^{6}$ Their community was small; the local teacher was a third cousin to the Looneys and kin by marriage to the Spencers. ${ }^{7}$

However, when Spencer's brother was accused of killing Looney's brother, the families stopped talking. And then Looney started talking, to just about anyone who would listen: "[The Spencers] are nothing but God damned negroes, and I can prove they are God damned negroes." ${ }^{.8}$ Adopting these words as a mantra, Looney- "thoroughly addicted to the abominable habit" of profanity - uttered them at the mill, at his store, at home, and in town. In the summer of 1911, his words flowed down the branches and forks and creeks wrinkling through Buchanan. Before the local school opened for the fall term, Looney approached his cousin, the teacher, told him to tell the Spencers that he called them "damned niggers," and declared

2. W. FITZHUGG BRUNDAGE, LYNCHING IN THE NEW SOUTH: GeORGIA AND VIRGINIA, 1880-1930, at 143 (1993); see also ELLER, supra note 1, at 168-72 (noting that, from 1900-1920, "the ethnic composition of the mountains" changed dramatically).

3. Petition at 7, Spencer v. Looney, 82 S.E. 745 (Va. 1914) (No. 2012). The 1920 census listed Buchanan County as entirely white, and all but four people were "native-born" Americans. See HUMBERT, supra note 1, at 10-11. A 1930 industrial survey suggested that "[a]mong such a homogenous population, industrialists need have little fear of labor disturbances." Id. at 36.

4. BRUNDAGE, supra note 2 , at 143.

5. Id. at 146. Buchanan County had only one recorded lynching between 1880 and 1930 . The day after Christmas 1909, a mob lynched a murder suspect named Henry Pennington-a white man. See id. at 282.

6. Transcript of Trial at 93-94, Spencer v. Looney (Va. 1912) (No. 2012) [hereinafter Spencer Transcript] (on file with Virginia State Law Library, Richmond, Va.) (testimony of George Spencer); see also Spencer, 82 S.E. at 748 (describing how Spencer and Looney "had been good friends" who "associate[d] gencrally" with each other).

7. Spencer Transcript, supra note 6, at 49 (testimony of Joseph McClanahan).

8. Brief of Counsel for Appellee at 5-9, Spencer v. Looney, 82 S.E. 745 (Va. 1914) (No. 2012) [hereinafter Spencer Appellee Brief].

9. Id. at 9 . 
that he would take his children out of school. "0 "They shan't go with negroes," he said. ${ }^{1 "}$

Then Looney sharpened his attack. He traveled to nearby Johnson County, Kentucky. "[T]hrough strenuous efforts, involving costs and expenses," 12 Looney found men who knew Spencer's grandfather-old men, on either side of eighty, who lived in places with names like Paintsville, Jennies Creek, Burnt Cabin, and Lick Fork, and knew Jordan Spencer, Sr., "[e]ver since the war, and before too."" These men remembered his thin lips, blue eyes, and "tolerably straight," long red hair, ${ }^{14}$ quite possibly "painted," with "a kind of a slick rim where his hat went." 15 One recalled that "a wild, drinking kind of a dissipated man" named Letcher Davis used to tell the Johnson County locals that Spencer had mixed blood, ${ }^{16}$ and others talked about nagging rumors that would pop up every now and then. Looney paid for a school official to accompany him on his expeditions. ${ }^{17}$ With affidavits in hand, Looney convinced the Rock Lick School District to expel Melvin Spencer from the third grade. George Spencer then sued Looney for slander, seeking damages of ten thousand dollars.

Spencer v. Looney ${ }^{18}$ was one of dozens of cases decided in the eras of slavery and segregation that hinged on the question of whether a plaintiff or defendant was white or black. During the past decade, legal historians have begun to excavate these bygone disputes, which involved wills, marriage and divorce, transportation, immigration and naturalization, and libel and slander. With few exceptions, two goals have motivated recent scholarship: proving that race is a social construction and showing how courts in the nineteenth and early twentieth centuries helped build America's racial infrastructure.

This Essay presents a more complex picture of race in the postReconstruction South in an attempt to develop a richer understanding of how the law of race worked. Cases that required a determination of a plaintiff's or defendant's racial identity provide rare glimpses into the private lives and worldviews of real people. Although contained within the

10. Spencer Transcript, supra note 6, at 50 (testimony of Joseph McClanahan).

11. Id. at 52.

12. Spencer, 82 S.E. at 746.

13. Spencer Transcript, supra note 6, at 115 (testimony of John D. Preston).

14. Id. at 81 (testimony of Thomas Horn).

15. Id. at 77 (testimony of John Estep) ("Q. Was Jordan Spencer Sr's hair kinky or curly? A. I could not state whether it was right kinky or not. There was a kind of slick rim where his hat went, but it was kindly turned up, but I could not say whether it was kinky or not.").

16. Id. at 64 (testimony of John W. Horn).

17. Id. at 108 (testimony of P.L. Johnson).

18. Spencer v. Looney, 82 S.E. 745 (Va. 1914). 
conventions of briefs, legal opinions, and direct and cross examination, ${ }^{19}$ their voices vividly express a largely unexplored degree of selfconsciousness about what race does and does not mean. Making sense of the private beliefs aired in courtrooms is an essential task of the legal history of race. Cases like Spencer v. Looney show people who exercised a surprising degree of tolerance in their everyday lives at a time of massive racial hysteria and who had a basic awareness that racial identity was something that could be disputed and creatively argued, at least in the courtroom.

After surveying the legal historiography, I explore what current scholars, with a few notable exceptions, have missed: that many of the historical actors understood that race is a social construction. For most legal historians, the actors in cases such as Spencer v. Looney-parties, lawyers, witnesses, judges, spectators, and contemporaneous commentators-have been useful only to the extent that their doings, presumably unconscious or unintentional, reveal inconsistencies about, and thus the socially constructed nature of, race. In fact, at the turn of the twentieth century, there was widespread discussion of the artificiality of the color line, in courtrooms, legal commentary, social science literature, journalism, and fiction. It is no exaggeration to say that at the height of Jim Crow, peopleeven and perhaps especially the most rabid of racists-understood what a legal fiction was.

At the root of at least some of this self-consciousness is a phenomenon in American social history that the law, as a forum where family secrets were uttered aloud, is uniquely positioned to reveal. Over the course of the nineteenth century, the United States shifted from an identity regime that recognized "mulattoes" as a distinct racial category to one that divided the world strictly into black and white. Although this transition has been generally regarded as a time when mulattoes were absorbed into a black world, it was also a time when many established themselves as white. That is to say, across the South at the turn of the twentieth century, ostensibly white people who were socially accepted as white had African ancestry.

This racially porous status quo was at odds with the extreme and often violent politics of segregation. While the most paranoid ideologies of "racial integrity" sought to classify every person with any African ancestry as black, this "one-drop rule" had the broad potential to be destabilizing for the white South. If no one's racial status was secure without an exhaustive genealogy, the governmental apparatus of segregation and white supremacy would be perpetually threatening to whites. Instead, statutory definitions of

19. See Ariela Gross, Beyond Black and White: Cultural Approaches to Race and Slavery, 101 COLUM. L. REV. 640, 650-51 (2001) ("[T]rial stories not only drew on familiar cultural narratives and were presented because of their cultural resonance, but ... the legal forum often shaped these stories, winnowed out certain elements and emphasized others ...."). 
race reflected the status quo, defining as white those people who had as much as one-fourth or one-eighth "Negro blood." Formalistic judicial enforcement of the color line preserved this status quo, making it difficult to prove that people who were accepted as white were in fact black and encouraging actions for damages such as Spencer $v$. Looney.

As a result, extreme segregationists sought to push the color line toward a one-drop rule by arguing that the more generous statutory definitions of race were absurd, illogical, and socially constructed - an ironic contrast to quite similar observations made by progressive scholars today. This complicated picture of race in the turn-of-the-century South has been absent from legal scholarship. At the heart of this Essay is an attempt to take race beyond conventional legal history and view cases about the color line as portals into a world of secret histories-whispered gossip, unstated understandings, and stories purposely forgotten.

\section{RACE IS A SOCIAL CONSTRUCTION}

In his 1994 article, The Social Construction of Race, Ian F. Haney López wrote that "[r]ace may be America's single most confounding problem, but the confounding problem of race is that few people seem to know what race is." ${ }^{20}$ Although conventional wisdom viewed race as a natural or biological fact, Haney López argued that "[r]ace must be viewed as a social construction. That is, human interaction rather than natural differentiation must be seen as the source and continued basis for racial categorization." ${ }^{, 21}$ This intellectual project of debunking notions of the immutability of race has not been a lonely one. Proving that race is a social construction and showing how race has been socially constructed are stated missions of most legal scholars of race. ${ }^{22}$ This Part will survey current

20. Ian F. Haney López, The Social Construction of Race: Some Observations on Illusion, Fabrication, and Choice, 29 HARV. C.R.-C.L. L. REV. 1, 5-6 (1994).

21. Id. at 27.

22. See, e.g., Donald Braman, Of Race and Immutability, 46 UCLA L. REV. 1375, 1380 (1999) ("I review, from the founding of the nation onward, the disagreement and deliberation over racial classifications, and the effect of these debates on constitutional law."); Adrienne D. Davis, Identity Notes Part One: Playing in the Light, 45 AM. U. L. REv. 695, 696 (1996) ("Using two cases from the early and mid-nineteenth century, I discuss how race is socially constnucted, why it matters, and how the process can appear in issues as dry as an allocation of the burden of proof." (emphasis omitted)); Michael A. Elliott, Telling the Difference: Nineteenth-Century Legal Narratives of Racial Taxonamy, 24 LAW \& SOC. INQUIRY 611, 614-15 (1999) ("[T]hose confronted by issues of race and racial difference drew from a compendium of competing ideas, ideas that were constantly being reshaped and redefined. Race, in other words, was being continually reinvented - and some in the nineteenth century recognized this process as surely as we do today."); Neil Gotanda, A Critique of "Our Constitution Is Color-Blind," 44 STAN. L. REV. 1, 28 (1991) (" "TT] he American racial categorization scheme is not only historically contingent, but, to some extent, legislatively determined."); Ariela J. Gross, Litigating Whiteness: Trials of Racial Determination in the Nineteenth-Century South, 108 YALE L.J. 109, 114-15 (1998) ("There are a number of claims included in the 'social construction' argument. First ... is the 
scholarship and consider how the issue of social construction has shaped the history of race and of the law's role in its development.

\section{A. A Brief Typology}

In the past decade, legal historians have untangled the thickets of rhetoric that courts have used to justify their rulings on the color line as logical, natural, or compelled by science. Through close readings of court decisions and, less often, analyses of legal briefs and trial transcripts, ${ }^{23}$ scholars have pointed out discreet contradictions and illogic in judicial reasoning from the earliest nineteenth-century cases onward. ${ }^{24}$ Even where the courts have seemed the most certain that they were merely channeling inevitable truths, their decisions in fact reveal race for what it is: a social construction. ${ }^{25}$

For example, two thoughtful articles ${ }^{26}$ have discussed how the Supreme Court in Plessy v. Ferguson, the 1896 case upholding a Louisiana statute requiring separate railway cars for blacks and whites, noted the "difference of opinion in the different states" as to "the question of the proportion of colored blood necessary to constitute a colored person., ${ }^{27}$ In some states, a black person was defined as anyone who had a black grandparent. In others, it was anyone who had a black great-grandparent. And in still others, it was anyone who was visibly black. ${ }^{28}$ Such varying definitions obviously belie the Plessy Court's confidence that Jim Crow laws were necessitated by the

claim that ... whether or not racial designations have a biological or anthropological basis in fact, the social meaning of race-which cultural attributes are attached to racial designations, which rights and disabilities accompany racial status, and so on-has changed over time and varied across space. ... For the purposes of this Article, ... I want to assume [this] version of the social construction of race, in order to open certain questions about how that construction might have taken place in the courtroom."); Cheryl I. Harris, Whiteness as Property, 106 HARV. L. ReV. 1709,1716 (1993) (describing the "construction of whiteness as property"); D. Marvin Jones, Darkness Made Visible: Law, Metaphor, and the Racial Self, 82 GEO. L.J. 437, 441 (1993) ("In this paper, I argue for a hermeneutic turn in our discourse on racial issues to address the figure of race as a problematic, a notion that is itself prior to and distinct from the inferences one makes about race and prior to social structures of race-based domination.").

23. See Gross, supra note 22, at 116-19 (discussing the importance of examining trial transcripts); Harris, supra note 22, at 1748 (quoting Brief for Plaintiff in Error at 9, Plessy v. Ferguson, 163 U.S. 537 (1896) (No. 210)).

24. See, e.g., Hudgins v. Wright, 11 Va. (1 Hen. \& M.) 134 (1806) (assigning to a slaveowner the burden of proving that three generations of women with straight black hair descended from a black slave and not a free Indian). This case is discussed in Davis, supra note 22, at 702-17, Gross, supra note 22, at 129-30, Haney López, supra note 20, at 1-5, and A. Leon Higginbotham, Jr. \& Barbara K. Kopytoff, Racial Purity and Interracial Sex in the Law of Colonial and Antebellum Virginia, 77 GEO. L.J. 1967, 1985-87 (1989).

25. See, e.g., Davis, supra note 22 , at 720 ("The courts rely on inconsistent notions of the nature of race, even as they confidently deploy race as a natural, observable category.").

26. Braman, supra note 22; Elliott, supra note 22.

27. 163 U.S. $537,552(1896)$.

28. See id:; Gilbert ThOMas STephenson, Race Distinctions IN AMERICAN LaW 15-16 (1910). 
existence of "racial instincts" and "distinctions based upon physical differences. ${ }^{29}$ The majority opinion's acceptance of a variable notion of the color line becomes proof positive that the Court "acknowledge[d] that racial status, at least as a legal matter, was a decidedly arbitrary statutory distinction." $" 30$

Other scholars have tracked the construction of race in how courts reified certain metaphors into notions that now seem natural and absolute. For instance, courts for two centuries have spoken of race in terms of fractions of black and white "blood." Even as such language resonates with the ideologically neutral authority of science, scholars have argued that it was merely a metaphor, and an imprecise one at that ${ }^{31}$ Such metaphors had ancient roots that were revived with the rise of pseudoscientific investigation of racial difference. ${ }^{32}$ Three commentators have observed that the use of these metaphors in nineteenth-century cases arose from a formalist legal impulse that enabled courts to think of race in terms of a more familiar and elegant conceptual framework: property. The conception of "blood" as a kind of title gave whites, as owners of this "property," the right to exclude blacks, forming a legal infrastructure of inequality. ${ }^{33}$

Finally, scholars have shown how scientific notions of race such as genealogy or physical appearance have never been the courts' sole or even preferred type of evidence for determining race.$^{34}$ In part, the color line was established, in the words of the South Carolina Supreme Court, by

29. Plessy, 163 U.S. at 551.

30. Braman, supra note 22 , at 1399 . Michael Elliott adopts a slightly different view:

This Plessy opinion does not go so far as to consider race to be the arbitrary instrument of power that we now think it to be, but Justice Brown hints at an awareness that the law does not simply reflect an order of racial difference prior to and outside of it. By letting this patchwork of conflicting state standards prevail, the Court shows that the law is complicit in the creation of race.

Elliott, supra note 22, at 618 .

31. Cheryl Harris notes the impossibility of measuring race by blood proportion: "[T]he degree of precision called for by the relevant standards or definitions rested on false assumptions that racial categories of prior ancestors had been accurately reported, that those reporting in the past shared the definitions currently in use, and that racial purity actually existed in the United States." Harris, supra note 22, at 1740.

32. Id. at 1739; Jones, supra note 22 , at $452-55$.

33. See Elliott, supra note 22, at 622 (describing how one judge's use of blood metaphors in People v. Dean, 14 Mich. 406 (1866), was a reluctant attempt at "finding a rational means to carry out admittedly irrational principles"); Harris, supra note 22, at 1740-41 ("Although the line of demarcation between Black and white varied..., courts universally accepted the notion that white status was something of value that could be accorded only to those persons whose proofs established their whiteness as defined by the law.... In effect, the courts erected legal 'No Trespassing' signs."); Eva Saks, Representing Miscegenation Law, RARITAN, Fall 1988, at 39, 41 ("Judges in miscegenation discourse used semiotic representation to create a new property in race: the metaphor of 'blood,' which functioned as title.").

34. At least one scholar has argued that genealogy and physical appearance are themselves criteria in tension with each other. See Davis, supra note 22, at 706-07 (arguing that genealogical evidence undermines the importance of physical appearance, although both types of evidence affirm white judicial control over the process of racial designation). 
"evidence of reputation as to parentage; and such evidence as was offered in the present case, of the person's having been received in society, and exercised the privileges of a white man." ${ }^{35}$ In a groundbreaking study of dozens of cases that were appealed to Southern state supreme courts in the nineteenth century, Ariela Gross documented the development of extensive evidentiary records regarding people's reputation and the "'performance' of whiteness"- the way a man exercised the rights and privileges of white citizenship or a woman showed "white" purity and moral virtue. Similarly, "evidence of whiteness in ... character, religious practices and beliefs, class orientation, language, [and] ability to intermarry" factored strongly in immigration cases heard between 1870 and 1952, a time in which federal law made proof of whiteness or blackness a prerequisite for naturalization. ${ }^{37}$ According to Haney López, "[t]he celebration of common knowledge and the repudiation of scientific evidence" in those cases proved that " $[\mathrm{r}] \mathrm{ace}$ is nothing more than what society and law say it is."

\section{B. Creating a Usable History}

The conclusion that race is a social construction is not, by itself, original. For nearly forty years, historians, philosophers, anthropologists, sociologists, and scientists have theorized and documented the historically contingent and often shifting meaning of race. ${ }^{39}$ As a matter of intellectual history, constructivist ideas have percolated throughout the twentieth century, from Franz Boas to Frantz Fanon. ${ }^{40}$ Recent scholarship has even

35. State v. Davis, 18 S.C.L. (2 Bail.) 558,560 (1831).

36. Gross, supra note 22 , at 156-57.

37. John Tehranian, Note, Performing Whiteness: Naturalization Litigation and the Construction of Racial Identity in America, 109 YALE L.J. 817, 821 (2000).

38. IAN F. HaNey López, WhITE by LaW: THE Legal CONSTRUCTION OF RACE 102-03 (1996).

39. See, e.g., Virginia R. Domínguez, White by Definition: Social Classification IN CREOLE LOUISIANA (1986); GEORGE M. FREDRICKSON, THE BLACK IMAGE IN THE WHITE MIND: THE DeBate on AFro-AMERICAN Character AND DESTINY, 1817-1914, at 320 (1971); THOMAS F. GOSSETT, RACE: THE HISTORY OF AN IDEA IN AMERICA (1963); REgINALD HORSMAN, RACE AND MANIFEST DESTINY: THE ORIGINS OF RACIAL ANGLO-SAXONISM 4-5 (1981); WINTHROP D. JORDAN, WHITE OVER BLACK (1968); EDMUND S. MORGAN, AMERICAN SLAVERY, AMERICAN FREEDOM: THE ORDEAL OF COLONIAL VIRGINIA (1975); MICHAEL OMI \& HOWARD WINANT, RACIAL FORMATION IN THE UNITED STATES: FROM THE 1960S TO THE 1990S, at 53-76 (2d ed. 1994); WILlIAM STANTON, THE LEOPARD's SPOTS: SCIENTIFIC ATTITUDES TOWARD RACE IN AMERICA, 1815-59 (1960); Anthony Appiah, The Uncompleted Argument: Du Bois and the Illusion of Race, in "RACE," WRITING, AND DIFFERENCE 21, 23 (Henry Louis Gates, Jr., ed., 1986); Barbara J. Fields, Ideology and Race in American History, in REGION, RACE, AND RECONSTRUCTION 143, 150 (J. Morgan Kousser \& James M. McPherson eds., 1982); Masatoshi Nei \& Arun K. Roychoudhury, Genetic Relationship and Evolution of Human Races, 14 EVOLUTIONARY BIOLOGY 1 (1982); Nancy Leys Stepan, Race and Gender: The Role of Analogy in Science, in ANATOMY OF RACISM 38, 39-4l (David Theo Goldberg ed., 1990).

40. See W.E.B. Du Bois, The Souls of Black Folk (1903); Frantz Fanon, Black Skin, WHITE MASKS (Charles Lam Markann trans., Grove Press 1967) (1952); Braman, supra note 22, at 1412-18 (tracing the rise of antiracism in the work of Franz Boas and Gunnar Myrdal); Thomas 
discerned traces of awareness of these notions in nineteenth-century judicial opinions, and Part II of this Essay will discuss turn-of-the-century critiques of race in greater detail. ${ }^{41}$

What makes the history of race worth telling for many legal commentators is its ready applicability to contemporary problems in policy and jurisprudence. ${ }^{42}$ As recently as 1990 , individual Supreme Court Justices were still describing race in antiquated terms of "blood" and biology. ${ }^{43}$ In equal protection cases, the Court's decision as to whether or not to subject discriminatory policies to the heightened standard of strict scrutiny, as opposed to rational basis review-often an outcome-determinative decision-is largely based on whether such policies affect groups defined by "immutable" traits. By disputing that judges have always regarded race as a biological fact, scholars such as Donald Braman have called for today's Court to reassess the immutability criterion and have suggested alternative strategies for equal protection litigants such as gays, who have emphasized the biological basis of sexual orientation in the attempt to qualify for heightened scrutiny. ${ }^{44}$ In a similar vein, scholars have traced the Court's hostility to affirmative action and its commitment to "color-blind constitutionalism" to discourses about race such as the equation of whiteness with property that, although cloaked in ideological neutrality, emerged during the nineteenth century as potent weapons for advocates of slavery, segregation, and white supremacy. By revealing the ideological

C. Holt, Marking: Race, Race-Making, and the Writing of History, 100 AM. HIST. REV. 1, 1-7 (1995) (comparing Du Bois and Fanon, and examining Du Bois's "intuitions about the social construction of race"); infra notes 76-81 and accompanying text. Even legal scholarship had attempted to grapple with the artificiality of race prior to the 1990 s. Section II.B of this Essay will discuss Gilbert Thomas Stephenson's 1910 treatise, Race Distinctions in American Law. This point is also made in a student note published in 1958 by the felicitously named John C. Calhoun. John C. Calhoun, Note, Who Is a Negro?, 11 U. FLA. L. REV. 235, 236 (1958) ("A comparison of Southern and border states' miscegenation statutes reveals considerable diversity among them as to the legal definition of Negro. This could result in the regrettable situation of a person being a white person today, and after a short migration, a Negro tomorrow.").

41. See infra Section II.A.

42. See, e.g., Braman, supra note 22; Gotanda, supra note 22; Harris, supra note 22; Luther Wright, Jr., Note, Who's Black, Who's White, and Who Cares: Reconceptualizing the United States's Definition of Race and Racial Classifications, 48 VAND. L. REV. 513, 519 (1995) ("[A]mid all of the evidence that racial classification is of great significance in American society, the law has provided no consistent definition of race and no logical way to distinguish members of different races from one another.").

43. HANEY LÓPEZ, supra note 38, at 101-02 ("For the Court, race remains natural."); Gotanda, supra note 22, at 29-32 (noting assumptions about the biological nature of race motivating Minnick v. California Department of Corrections, 452 U.S. 105, 128-29 (1981) (Stewart, J., dissenting), and Saint Francis College v. Al-Khazraji, 481 U.S. 604 (1987) (White, J.), and discussing Justice Scalia's "widely reported exchange with counsel" in Metro Broadcasting v. FCC, 497 U.S. 547 (1990)).

44. See Braman, supra note 22. 
baggage weighing on color-blind jurisprudence, history becomes a brief advocating that the Court not turn its back on remedies for past inequality. ${ }^{45}$

Recognizing race as a social construction also serves an interest much broader than reinvigorating the judicial enforcement of civil rights; for legal scholars, history drives a stake through racism's heart. The almost obligatory conclusion for histories of race expresses hope that the truth will set the United States free. "[A] major step in the dismantling of the racial stratification of our nation will come from explicit recognition by the courts that race is a social construction, not an inherent part of human existence or a scientific fact," explains a typical piece. ${ }^{46}$ "Only then will we be able to recognize racial division as nothing more than a subjective and irrational perception that oppresses us all; only then will our nation set out on the path towards equality for all its people. ${ }^{, 47}$ Even the more sober assessments of the effects of this type of scholarship read like calls to arms in the fight for racial justice. ${ }^{48}$

45. See Gotanda, supra note 22; Harris, supra note 22, at 1766-68 ("The assumption that whiteness is a property interest entitled to protection is an idea born of systematic white supremacy and nurtured over the years, not only by the law of slavery and 'Jim Crow,' but also by the more recent decisions and rationales of the Supreme Court concerning affirmative action."); cf. Robert W. Gordon, Critical Legal Histories, 36 STAN. L. REV. 57, 57 (1984) ("[I]n the less common situations in which lawyers have used history to criticize the status quo, they have usually resorted to social and economic history, to show that the original social context of a legal rule reveals it was adopted for wicked or obsolete reasons ....").

46. Tehranian, supra note 37 , at 848 ; see also Davis, supra note 22 , at 717 ("Categorical confusion creates ruptures in the security of our racial taxonomic structure, calling into question the practices by which we identify and label people. It is at these times that progressive lawyers, activists, and judges can cast light into the breach and demonstrate the hegemonic functioning of American racial construction, enabling counter-hegemonic moves. By destabilizing the seeming determinacy of race, we can also destabilize and better resist the inevitable privileging and subordinating dynamics criss-crossing the American racial map."); Haney López, supra note 20 , at 62 (" $[\mathrm{B}] \mathrm{y}$ choosing to resist racial constructions, we may emancipate ourselves and our children.... [R]ace is not an inescapable physical fact. Rather, it is a social construction that, however perilously, remains subject to contestation at the hands of individuals and communities alike.").

47. Tehranian, supra note 37 , at 848 .

48. See, e.g., Elliott, supra note 22 , at $633-34$ ("The ability of the hegemonic order-in this case represented by the law-to incorporate ideas and traditions that are inconsistent with one another has made race .... a set of social beliefs so flexible that they are capable of surviving the most withering intellectual attacks.... If those of us in institutions of power hope for a more egalitarian society, we should acknowledge that retooling the language of race may not be as immediately crucial as listening to the stories that we can already hear-stories that are being used to tell the differences that perpetuate racial inequality."); Gross, supra note 22 , at 185 ("To recognize the contestability of law is only to see how much work still lies ahead. For if 'race' in the past was more mobile and more contested than previously thought, yet still remained the basis for the thoroughgoing social, legal, and political subordination of African Americans, it should not surprise us that current efforts to 'destabilize' race, to break down or refuse to recognize racial categories, have failed to topple the existing racial hierarchy."). 


\section{Drawbacks to Usable Histories}

However useful the color-line cases may be in ongoing struggles for equality, situating histories of race within present-day debates tends to iron out the complexities of the past. When the important conclusion to draw is that race is a social construction, there is little need to inhabit the worlds and minds of individual lawyers, litigants, witnesses, and judges. Instead, it is enough to show that courts relied on contradictory statutory definitions of race, historically derived metaphors for race, ${ }^{49}$ or performative as opposed to scientific evidence. ${ }^{50}$

The dearth of attention given to individual agency is rooted in an incomplete development of the role of law in Southern society and culture. By some accounts, law is a cipher for prevailing beliefs of the natural, immutable character of race and an instrument of white supremacy. ${ }^{51}$ In their hope that understanding the law of race will help end racism, all accounts subscribe to the belief that law has had an enormous role in

49. Harris's work on whiteness as property, for example, focuses on the function of these metaphors as tools of oppression and how they "blinded society to the systems of domination that work against so many." Harris, supra note 22, at 1791; see also Davis, supra note 22, at 710 ("This shifting construction of both blackness and whiteness illuminates both the fluidity of racial classifying practices, and the inexorable nature of securing the white rights."). This perspective leaves little sense that the judges who employed these metaphors had any idea of the complexity and contradictions presented by the cases before them. Elliott, citing ambivalent language in a few judicial opinions, injected a touch of appreciation for the ability of judges to recognize that "blood" was an imperfect metaphor. Elliott, supra note 22, at 633-34.

50. Thus, even though Ariela Gross situates her study of reputational and performative evidence of whiteness in a rich narrative of social, intellectual, and local history, see, e.g., Gross, supra note 22, at 124-28 (discussing the rise in the 1850s of blurry "middle grounds" between slave and free and black and white, and the prevalence of anxiety over and stories about white slavery), she concentrates on the fact that juries and judges valued this evidence, not on what such evidence revealed about the worlds of individual litigants and everyone else in the courtroom. Although the latter point may seem out of place in what is, after all, legal history, see id. at 116 n.20 (distinguishing Gross's own work from studies of some of the same cases by Martha Hodes and Walter Johnson on the grounds that "[n]either of their case studies are primarily concerned with legal history"), Gross has overdrawn the distinction between social and legal history. Part II of this Essay will attempt to show that a focus on individual world views as they intersect with the legal process can yield significant insights into the law of race.

51. See, e.g., Davis, supra note 22, at 696 ("[T]he court's reasoning was driven not by the interests of the immediate parties, but rather by a larger, perhaps unconscious, desire to define white identity and serve white liberty interests."); Harris, supra note 22, at 1737-38 ("The law assumed the crucial task of racial classification, and accepted and embraced the then-current theories of race as biological fact... The law relied on bounded, objective, and scientific definitions of race...t to construct whiteness as not merely race, but race plus privilege. By making race determinant and the product of rationality and science, dominant and subordinate positions within the racial hierarchy were disguised as the product of natural law and biology rather than as naked preferences. Whiteness as racialized privilege was then legitimated by science and was embraced in legal doctrine as 'objective fact." (citations omitted)); Jones, supra note 22, at 451-52 (describing "the institution of law" as a "mechanism for smuggling the metaphor of race into ordinary language"). Robert W. Gordon has labeled this functionalist mode "[1]aw as (legitimating) ideology." Gordon, supra note 45, at 93. 
constructing race and can be similarly powerful in deconstructing it. ${ }^{52}$ But the focus of these histories, however understandable, fails to locate the law of race convincingly within a larger world.

\section{Looney Revisited}

Spencer $v$. Looney would find a comfortable place in today's legal histories. Witnesses on both sides testified about the appearance and body odor $^{53}$ of various members of the Spencer family as well as their attendance at white schools and churches. This juxtaposition of testimony about physical traits and social performance would extend Ariela Gross's conclusion that witnesses in antebellum cases "introduced a discourse of race as a set of associations and performances that competed with the discourse of race as ancestry, as science, and as physical marker." ${ }^{.54}$ On appeal from a jury verdict for the defendant, the Virginia Supreme Court emphasized the Spencers' good standing in the white community, found error in the trial court's refusal to admit photographs of the plaintiff's grandfather and cousins, and disregarded a defense expert imported from Norfolk, a man who had studied both medicine and the law and who testified upon looking at George and Melvin Spencer from the witness stand that "there is some negro there." 55 The court's common-sense approach would certainly fit Haney López's view of the legal construction of race. But in the context of another set of questions, Spencer v. Looney

52. See, e.g., HANEY LOPEZ, supra note 38, at 10 ("The operation of law does far more than merely legalize race; it defines as well the spectrum of domination and subordination that constitutes race relations."); Braman, supra note 22, at 1463 ("Courts continue to contribute to the institutionalization of a number of classificatory schemes, models of the world that mediate our most mundane and personal interactions.... As we create and employ social institutions to develop the terms and significance of difference in our society, the extent to which we understand the basis of that difference as natural, and thus beyond our control, or social, and thus within human reach, is no small thing."); Gross, supra note 22, at 119 \& n.23, 181 ("The courtroom conclusions about how to decide whether someone was black or white... reverberated throughout Southern culture because of the importance of the courtroom as a cultural arena."); Haney López, supra note 20, at 3 ("[T]he law serves not only to reflect but to solidify social prejudice, making law a prime instrument in the construction and reinforcement of racial subordination."); cf. Gordon, supra note 45, at 109 (describing Critical views of the law as "[c]onstitutive of [c]onsciousness").

53. Lawyers asked numerous witnesses about whether the Spencers had a "peculiar odor that is peculiar to the negro." E.g., Spencer Transcript, supra note 6, at 62 . The synesthesic testimony of witness W.B. Leemaster could inspire a separate essay on the social construction of body odor. When the defense attorney asked, "Did you ever smell [George Spencer] when he got hot?", Leemaster testified, "Yes, he didn't smell as loud as some ... but he has the same scent as a negro." Id. at 113. When asked on cross examination if he himself did not "smell like a negro," Leemaster replied, "No, sir. I don't smell as loud as a negro." Id. Although the testimony established that Jordan Spencer, Sr., "[s]melled a little bit, when he was a little hot," the consensus among witnesses was that his odor was "not so heavy and strong." Id. at 66 (testimony of John W. Horn).

54. Gross, supra note 22, at 180-81.

55. Spencer Transcript, supra note 6, at 149-50 (testimony of Eugene A. Billisoly). 
starts to create a different picture of history and a different picture of the law. Part II begins by exploring the extent to which Southerners at the turn of the twentieth century understood the inconsistencies and contradictions about race that have so preoccupied legal scholars at the turn of the twentyfirst.

\section{RACE WAS A SOCIAL CONSTRUCTION}

Q. [D]id you ever hear it reported he had negro blood about him?

A. I might have heard it, and I might not.

-Deposition of John W. Horn Spencer v. Looney ${ }^{56}$

Much of the testimony in Spencer v. Looney came from elderly men who had grown up and grown old knowing the plaintiff's grandfather. In depositions taken in the law offices of Howes \& Howes, Paintsville, Kentucky, ${ }^{57}$ these men remembered Jordan Spencer, Sr., "when he was hot and when he was cold, when he was drunk and when he was sober." 58 Although they probably had little experience in adversarial legal proceedings, they proved to be cagey witnesses. Eighty-two-year-old John W. Horn, quoted in the epigraph above, set the tone for many of the interviews that followed over several days in early May 1912. J.Q. Horn, age sixty-five, declined to say whether Spencer was "a man of pure Caucasian blood": "[T]hat I don't know anything about, I don't bother with." 59 Asked the same question - "Judging of what you have seen of Jordan Spencer, Sr. would you class him as a man of pure Caucasion [sic] blood?"-sixty-eight-year-old Tom Horn replied, "I don't know anything about anyone's blood, no matter who the man is." not to evade the defense attorney's questions, John Estep, whose memory of Spencer went back to 1869 , also refused to give his "best opinion" on Spencer's "pedigree": "I have not formed any good opinion about it. It was none of my business."

56. Spencer Transcript, supra note 6, at 63 (testimony of John W. Horn).

57. Id. at 58-59.

58. Id. at 66 (testimony of John W. Horn).

59. Id. at 75-76 (testimony of J.Q. Hom).

60. Id. at 82 (testimony of Thomas Horn).

61. Id. at 78 (testimony of John Estep); see also id. at 88-89 (testimony of A.L. Rice) ("I would not want to judge a man, because he might and he might not have negro blood in him, I don't know you see."). 
Such words clash with the generally accepted picture of the postReconstruction South. By all accounts, the color line was everyone's business at the time Spencer v. Looney was tried. Although the wave of Jim Crow legislation starting in the 1890 s did not radically change social relationships in a South already largely segregated ${ }^{62}$ the new laws did mark a break with the past. Anxieties about race saturated

every conceivable situation in which whites and blacks might come into social contact: from public transportation to public parks, from the workplace to hospitals, asylums, and orphanages, from the homes for the aged, the blind, deaf, and dumb, to the prisons, from saloons to churches. ... The signs "White Only" and "Colored" (or "Negroes") would henceforth punctuate the southern landscape, appearing over the entrances to parks, theaters, boardinghouses, waiting rooms, toilets, and water fountains. ${ }^{63}$

Thousands of lynchings in the three decades before World War I gave menacing force to everyday reminders of white supremacy. ${ }^{64}$ The air resounded with speeches given by demagogues like "Pitchfork Ben" Tillman, South Carolina governor and United States senator, who traveled

62. See Edward L. Ayers, The Promise of the NeW SOUTH: LifE After RECONSTRUCTION 136 (1992) ("Some things about the relations between the races had been established quickly after emancipation. Schools, poor houses, orphanages, and hospitals, founded to help people who had once been slaves, were usually separated by race at their inception."); LEON F. LITWACK, TROUBLE NN MIND: BLACK SOUTHERNERS IN THE AGE OF JIM CROW 229-30 (1998) ("Even the Radical legislatures in which blacks played a prominent role made no concerted effort to force integration on unwilling and resisting whites, especially in the public schools; constitutional or legislative provisions mandating integration were almost impossible to enforce.").

63. LiTwACK, supra note 62, at 233; see also id. at 246 (describing the use of separate Bibles to swear in black and white witnesses in Wake County Superior Court in North Carolina). A typical, if florid, example of the rhetoric that accompanied this new breed of extreme segregationism can be found in William Benjamin Smith's The Color Line: A Brief in Behalf of the Unborn:

The moment the bar of absolute separation is thrown down in the South, that moment the bloom of her spirit is blighted forever, the promise of her destiny is annulled, the proud fabric of her future slips into dust and ashes. No other conceivable disaster that might befall the South could, for an instant, compare with such miscegenation within her borders. Flood and fire, fever and famine and the sword-even ignorance, indolence, and carpet-baggery-she may endure and conquer while her blood remains pure; but once taint the well-spring of her life, and all is lost-even honour itself.

WILLIAM BENJAMIN SMITH, THE COLOR LINE: A BRIEF IN BEHALF OF THE UNBORN 8-9 (1905), reprinted in ANT1-BLACK THOUGHT, 1863-1925: RACIAL DETERMINISM AND THE FEAR OF MISCEGENATION POST-1900, at 45, 62-63 (John David Smith ed., 1993).

64. For more information on lynchings in the three decades before World War I, see AYERS, supra note 62, at 155-59; BRUNDAGE, supra note 2, at 3, 7-8; FREDRICKSON, supra note 39, at 256-82; MARTHA HODES, WHITE WOMEN, BLACK MEN: IlliCIT SEX IN THE NINETEENTHCENTURY SOUTH 176-208 (1997); LITWACK, supra note 62, at 280-325; and JOEL WILLIAMSON, THE CRUCIBLE OF RACE: BLACK-WHITE RELATIONS IN THE AMERICAN SOUTH SINCF EMANCIPATION 183-89 (1984). 
the South warning of the pervasive threat of black rapists. ${ }^{65}$ Thomas Dixon's best-selling novels told similar stories of unrestrained black sexuality and glorified Ku Klux Klan violence; ${ }^{66}$ rich whites in towns such as Louisburg, North Carolina, chartered trains to see big-city dramatic productions of Dixon's work. ${ }^{67}$ Even "New South" moderate Henry W. Grady advocated aggressive segregation: "The supremacy of the white race of the South must be maintained forever, and the domination of the negro race resisted at all points and at all hazards ....,68

Although historians have described complicated and often humane responses to ambiguities of racial identity before the Civil War, such responses are said to have ceased entirely in the racial hysteria of the postReconstruction era. ${ }^{69}$ Yet the testimony in Spencer $v$. Looney suggests that there remained cool spots in the crucible of race, where racial identity was personal and casually worn and where rumors of race did not compel mob action.

The local tolerance of a certain, albeit small, amount of racial ambiguity in Spencer $v$. Looney was not an entirely anomalous phenomenon. In the world outside Buchanan County, ideas about race were often more casual and more complicated than most historical accounts would suggest. The triumph of radical racism did not destroy all opposition. Even when mobs specifically targeted dissenting voices-journalists such as Ida Wells and Alex Manly were forced into exile for questioning white morality and the sexual mythologies that justified lynching ${ }^{70}$-people continued to attack the assumptions underlying segregation. At the height of Jim Crow, blacks and whites clearly and repeatedly discussed the artificiality of the color line. These discussions were hardly confined to the province of nineteenth-century social science and "system[s] of racial classification." ${ }^{71}$ The social construction of race is not an idea original to

65. LITWACK, supra note 62 , at 302-03.

66. See ThOMAS DiXON, JR., THE Clansman (1905); THOMAS DIXON, JR., THE LEOPARD'S SPOTS (1902); THOMAS DIXON, THE SINS OF THE FATHER (1912).

67. The local newspaper reported breathlessly that the Seaboard Air Line ran a special train "[t]o accommodate the large number of people in Louisburg and the other points between here and Raleigh, who desired to see the 'Clansman'-Tom Dixon's new play, which is creating so much interest throughout the country .... All who we have heard express themselves were highly pleased with the performance." To See the Clansman, FRANKLIN TIMES (Louisburg, N.C.), Oct. 6, 1905, at 3.

68. LITWACK, supra note 62, at 218 (quoting THOMAS F. GoSSETT, RACE: THE HISTORY OF AN IDEA IN AMERICA 264 (1963)).

69. See, e.g., HODES, supra note 64, at 121-22 ("Only with the dernise of slavery as keeper of the social order would white Southerners react almost uniformly to sex between a white woman and a black man with lethal fury.").

70. Ray StanNard Baker, Following the Color LINE: AMERICAN Negro Citizenship IN THE PROGRESSIVE ERA $160-61$ \& n.3 (Harper Torchbooks 1964) (1908); LITWACK, supra note 62 , at $313-15,429-30$.

71. Braman, supra note 22, at 1410; see also ChARLES B. DAVENPORT, HEREDITY OF SKIN COLOR IN NEGRO-WHITE CROSSES (1913) (rejecting the possibility of atavism). 
the late twentieth century. The ironies and illogic of race were fodder for public intellectuals, journalists, novelists, and lawyers even in the age of Plessy v. Ferguson.

\section{A. The Irony of Race: Turn-of-the-Century Critiques of the Color Line}

African-American culture simmered with awareness of the absurdities of the color line, ${ }^{72}$ to the extent that W.E.B. Du Bois mocked a general tendency among African Americans to "deprecate and minimize race distinctions, to believe intensely that out of one blood God created all nations, and to speak of human brotherhood as though it were the possibility of an already dawning to-morrow." ${ }^{, 73}$ Although Du Bois wrote in 1897 that "in our calmer moments we must acknowledge that human beings are divided into races, ${ }^{, 74}$ even he declared fourteen years later in the pages of the Crisis that "physical characteristics are ... too indefinite and elusive to serve as a basis for any rigid classification or division of human groups." ${ }^{.75}$ Others were more consistent and forceful in their critiques. ${ }^{76}$

One of the most sophisticated thinkers about race was Charles W. Chesnutt, a successful court stenographer, lawyer, and author in turn-of-thecentury Cleveland. Between 1899 and 1905, Houghton, Mifflin \& Co. and Doubleday, Page \& Co. published three novels by Chesnutt as well as two collections of short stories that had first appeared in the Atlantic Monthly. From the 1880 s until his death in 1932, Chesnutt also wrote nearly eighty speeches and newspaper columns. Much of his writing "ran along the color line, the vaguely defined line where the two major races of the country meet." ${ }^{, 77}$ With an audience of unprecedented size for an African-American writer, Chesnutt skewered contemporary assumptions about "that intangible

72. See. e.g., Nell Irvin Painter, "Social Equality," Miscegenation, Labor, and Power, in THE EVOLUTION OF SOUTHERN CULTURE 47, 57 (Numan V. Bartley ed., 1988) ("Whereas most whites believed that one's worth depended on one's 'blood,'... blacks usually traced individual attainment to favorable circumstances. Blacks denied that race predicted one's abilities, insisting that given the proper advantages, any man-black, brown, or yellow-could become a gentleman, any woman a lady.").

73. W.E.B. DU BOIS, THE CONSERVATION OF THE RACES (1897), reprinted in W.E.B. DU BoIS: WRITINGS 815, 815 (Nathan Irvin Huggins ed., 1986); see also LITWACK, supra note 62, at 240 (describing black folklore and humor that targeted the absurdities of segregation and racial etiquette).

74. DU BOIS, supra note 73 , at 815 .

75. W.E.B. Du Bois, Races, CrISIS, Aug. 1911, at 157, 158.

76. See Appiah, supra note 39 , at 35 (discussing Du Bois's failure to "completc[] the escape from race").

77. Charles W. Chesnutt, Remarks of Charles Waddell Chesnutt, of Cleveland, in Accepting the Spingarn Medal at Los Angeles (July 3, 1928), in CHARLES W. CHESNUTT: ESSAYS AND SPEECHES 510, 514 (Joseph R. McElrath, Jr., et al. eds., 1999) [hereinafter ESSAYS AND SPEECHES]. 
something which we call race." "Distinctions of color are unduly emphasized in the United States," he wrote. ${ }^{79}$ "As a matter of sociological interest, it is perhaps well enough to keep track, in a certain large sense, of the progress and development of this class of our citizens. But as between man and man the color of a person should be a purely personal and private matter. ${ }^{180}$ In a 1900 essay, Chesnutt couched his critique in language more recognizable to today's reader: "It is only a social fiction, indeed, which makes of a person seven-eighths white a Negro; he is really much more a white man." $" 81$

As one might expect from an attorney, Chesnutt had a strong interest in the statutes that set the color line, musing, "I could almost write a book about these laws, their variations, their applications and curious stories that one hears continually concerning them." ${ }^{, 82}$ Chesnutt spent the bulk of his 1889 essay, What Is a White Man?, documenting how "[t]he states vary slightly in regard to what constitutes a mulatto or person of color, and as to what proportion of white blood should be sufficient to remove the disability of color." blood," others had one-fourth rules, and still others were more liberal. ${ }^{84}$ The existence of such laws showed the artificiality and manipulability of race. Discussing an antebellum case in South Carolina that refused to set any formal "line of distinction," ${ }^{85}$ Chesnutt speculated that "[p]erhaps it may be attributed to the fact that the colored population of South Carolina always

78. ChaRles W. ChesnutT, Her Virginia Mammy, in THE WIFE OF HIS YOUTH AND OTHER STORIES OF THE COLOR LINE 25, 26 (Gregg Press, Inc. 1967) (1899). 565.

79. Charles W. CheSNUtT, The Term Negro, in ESSAYS AND SPEECHES, supra note 77, at

80. Id. at 566. Chesnutt's short story, Her Virginia Mammy, epitomizes his observations of the irrelevance of race in a culture obsessed with it. The story concerns Clara, a woman who refuses to marry a blue-blooded suitor named Winthrop because she was orphaned and adopted and remains uncertain about her family background. Clara only consents after an elderly lightskinned black woman appears at her place of work and tells her that she came from the first families of Virginia. Her suitor realizes that this woman is, in fact, Clara's mother - and does not care. See CHESNUTT, supra note 78, at 33 ("We are all worms of the dust, and if we go back far enough, each of us has had millions of ancestors; peasants and serfs, most of them; thieves, murderers, and vagabonds, many of them, no doubt; and therefore the best of us have but little to boast of."). Chesnutt's sense of irony was a good match for his editor at the Atlantic, William Dean Howells, who himself wrote a novel quite similar to Her Virginia Mammy. Rhoda Aldgate, heroine of An Imperative Duty, refuses a proposal of marriage by gasping, "Never! . . I am a negress!" Her suitor responds, "Well, not a very black one. Besides, what of it, if I love you?" W.D. HOWELLS, AN IMPERATIVE DUTY 139 (1892).

81. ChARLES W. CHESNUTT, The Future American: A Complete Race-Amalgamation Likely To Occur, BOSTON EVENING TRANSCRIPT, Sept. 1, 1900, reprinted in ESSAYS AND SPEECHES, supra note 77 , at $131,134$.

82. CHARLES W. CHESNUTT, The White and the Black, BOSTON EVENING TRANSCRIPT, Mar. 20,1901 , reprinted in id. at $139,141$.

83. ChARles W. CheSNUTT, What Is a White Man?, InDEPENDENT (New York), May 30, 1889 , reprinted in id. at 68,69 .

84. Id. at $69-70$.

85. Id. at 70 (quoting State v. Davis, 18 S.C.L. (2 Bail.) 558,558 (1831)). 
outnumbered the white population, and the eagerness of the latter to recruit their ranks was sufficient to overcome in some measure their prejudice against the Negro blood." $" 86$

These legal issues resurfaced in Chesnutt's first novel, The House Behind the Cedars, in a scene in which a main character, John Waldenwho has African ancestry but is "no darker than many a white boy bronzed by the Southern sun" ${ }^{\prime 87}$-asks an elderly North Carolina judge to train him to be a lawyer. At first, Judge Archibald Straight refuses to help Walden. "Lawyers go by the laws---they abide by the accomplished fact; to them, whatever is, is right," Straight says. "The laws do not permit men of color to practice law ...." Bo calf," ${ }^{89}$ Straight changes his mind because outside North Carolina, Walden would be legally white:

As you have all the features of a white man, you would, at least in South Carolina, have simply to assume the place and exercise the privileges of a white man.... [T] he matter has been adjudicated there in several cases, and on the whole I think South Carolina is the place for you. ${ }^{90}$

If the laws were "accomplished fact," Carolina and South Carolina enabled Chesnutt to show that the color line was anything but--to convince a judge, and presumably readers, that it was merely a short step from being "black as ink" to being a "Caucasian fellow citizen." ${ }^{.93}$

Chesnutt was not alone in understanding that laws determining "where black leaves off and white begins" complicated the race question. ${ }^{94}$ Pudd'nhead Wilson, an 1894 novella by Mark Twain about a slave's child switched at birth with the master's child, was premised on the "fiction of law and custom" that could make visibly white people legally black. ${ }^{95}$ Ten

86. Id. at 71 .

87. Charles W. Chesnutt, The house Behind the Cedars 167 (Univ. of Ga. Press 1988) (1900).

88. Id. at 170 .

89. Id. at 171 .

90. Id. at 172 .

91. Id. at 170 .

92. Id.

93. Id. at 172.

94. BAKER, supra note 70 , at 151

95. The slave, Roxy, "was as white as anybody, but the one-sixteenth of her which was black out-voted the other fifteen parts and made her a negro. She was a slave, and salable as such." SAMUEL LANGHORNE ClemENS, PUDD'NHEAD WILSON AND THOSE EXTRAORDINARY TWINS 8-9 (Sidney E. Berger ed., W.W. Norton 1980) (1894). In a passage edited out of the published version, Roxy's son, upon learning the truth about his ancestry, ponders the meaning of his white and black "blood": 
years later, journalist Ray Stannard Baker began traveling through the South for a series of magazine articles that became Following the Color Line. "I "I had not been long engaged in the study of the race problem," Baker wrote, "when I found myself face to face with a curious and seemingly absurd question: "What is a Negro?",97 Baker identified a widespread inability of white Southerners-police, judges, railroad conductors, juries in "almost innumerable cases," and even vigilante mobs-to "decide who is and who is not a Negro." Law professor Gilbert Thomas Stephenson examined Baker's observations in his 1910 treatise, Race Distinctions in American Law. "If race distinctions are to be recognized in the law," Stephenson wrote, "it is essential that the races be clearly distinguished from one another." ${ }^{.99}$ Yet drawing the color line "is one of the most perplexing and, at times, most embarrassing [questions] that has faced the legislators and judges."100 Quoting Baker at length, Stephenson wrote that the law simply could not draw a perfect color line, given the physical diversity of the African-American population: "It is this gradual sloping off from one race into another which has made it necessary for the law to set artificial lines."

Whence came that in him which was high, $\&$ whence that which was base? That which was high came from either blood, \& was the monopoly of neither color; but that which was base was the white blood in him debased by the brutalizing effects of . . slaveowning, with the habit of abuse which the possession of irresponsible power always creates $\&$ perpetuates, by a law of human nature. So he argued.

Samuel Clemens, Pudd'nhead Wilson 241-42 (1893) (unpublished manuscript, on file with the Pierpont Morgan Library, New York) (MA 881, 882); see also SHELlEY FISHER FISHKIN, WAS HUCK BLACK?: MARK TWAN AND AFRICAN-AMERICAN VOICES 122-26 (1993) (describing Twain's "rejection of a hierarchy of color").

Not every contemporaneous reader interpreted Pudd'nhead Wilson as a subversion of the color line. In the case of a man who sought an annulment from his wife on the grounds that he had unwittingly married a black woman in contravention of North Carolina's antimiscegenation laws - and a case that shows that a sharp lawyer is not necessarily a sharp literary critic-the husband's brief quoted Pudd'nhead Wilson as a "grim lesson" justifying a hard line on race issues:

[Twain's] octoroon heroine, mother of a child of blue-blooded paternity, speak[s] the truth of the ages to her bastard offspring, when she tells him that "thirty-one thirtyseconds of you is white, and one thirty-second is nigger, and that part is your soul, and you is a nigger in your heart, and always will be."

Plaintiff's Brief at 2, Ferrall v. Ferrall, 69 S.E. 60 (N.C. 1910) (No. 151) [hereinafter Ferrall Plaintiff's Brief] (on file with North Carolina Superior Court Library, Raleigh, N.C.).

96. BAKER, supra note 70 .

97. Id. at 151 .

98. Id. at $151-53$.

99. STEPHENSON, supra note 28 , at 12 .

100. Id.

101. Id. at 14. This basic insight makes Stephenson's treatise not far removed from scholarship written some ninety years later. Compare id. at 17 ("Some States have allowed facts other than physical characteristics to be presumptive of race. Thus, it has been held in North Carolina that, if one was a slave in 1865 , it is to be presumed that he was a Negro. The fact that one usually associates with Negroes has been held in the same State proper evidence to go to the jury tending to show that he is a Negro. If a woman's first husband was a white man, that fact, in Texas, is admissible evidence tending to show that she is a white woman."), with Gross, supra 


\section{B. White Skin, White Masks}

Legally drawn color lines were not only widely understood to be artificial, but they also pointed to a social phenomenon that has not been widely explored: that a sizable number of people legally and socially accepted as white in the post-Reconstruction South had African ancestry. ${ }^{102}$ Chesnutt trumpeted this issue in a newspaper column under the headline $A$ Stream of Dark Blood in the Veins of the Southern Whites:

A more certain proof of the fact that Negro blood is widely distributed among the white people may be found in the laws and judicial decisions of the various States. Laws, as a rule, are not made until demanded by a sufficient number of specific cases to call for a general rule; and judicial decisions of course are never announced except as the result of litigation over contested facts. There is no better index of the character and genius of a people than their laws. ${ }^{103}$

Chesnutt's observation has not been accounted for in the history of race in the United States. In the conventional account, the potential for a triracial social order in the South-white, mulatto, and black - collapsed into a white-black paradigm in the years leading up to the Civil War. ${ }^{104}$ Free mulattoes responded to white hostility by identifying themselves with the rest of African America; indeed, they had little choice but to "be made black.... There was no middle ground in the organic society, no place for

note 22, at 156 ("The most striking aspect of "race" in the nineteenth-century racial determination trials was not so much the biologization emphasized by earlier writers, but its performative and legal aspects. Proving one's whiteness meant performing white womanhood or manhood, whether doing so before the court, or through courtroom narratives about past conduct and behavior.").

102. The roots of such a social phenomenon run back to the colonial period. See JAMES Hugo JOHNSTON, RACE RELATIONS IN VIRGINIA AND MisCEGENATION IN THE SOUTH, $1776-$ 1860 , at 191-92 (1970) ("The intermixture of races had become so extensive by the end of the colonial period that many mulattoes seem to have lost all the distinguishing physical features of the Negro.").

103. Charles W. CheSNUTT, The Future American: A Stream of Dark Blood in the Veins of the Southern Whites, in ESSAYS AND SPEECHES, supra note 77, at 126, 129-30.

104. See IRA BERLIN, Slaves Without MASTERS: THE FrEe NEgRo IN THE ANTEBElluM SOUTH 343 (1974); EUGENE D. GENOVESE, ROLL, JORDAN, ROLL: THE WORLD THE SLAVES MADE 431 (1974) (describing how white attitudes "drove the mulattoes into the arms of the blacks, no matter how hard some tried to build a make-believe third world for themselves"); JOEL Williamson, NEW PEOPle: Miscegenation aNd Mulattoes IN THE UNITEd States 62 (1980) ("[D]ominant white society moved from semiacceptance of free mulattoes, especially in the lower South, to outright rejection. As mulatto communities in the $1850 \mathrm{~s}$ confronted an increasingly hostile white world implementing increasingly stringent rules against them in the form either of laws or of social pressures, they themselves moved from a position of basic sympathy with the white world to one of guarded antagonism. In the movement the mulatto elite gave up white alliances and picked up black alliances."). See generally Robert Brent Toplin, Between Black and White: Attitudes Toward Southern Mulattoes, 1830-1861, 45 J. S. HIST. 185 (1979). 
one who was neither white nor black." ${ }^{05}$ After Reconstruction, white Southerners did not merely view people of mixed race as black; they often targeted mulattoes as the quintessence of blackness, with much of the propaganda about black rapists identifying mulattoes as particularly vicious "fiend[s]." Adhering to the black-white conception of race, Professor Stephenson could write in 1910 that "[m]iscegenation has never been a bridge upon which one might cross from the Negro race to the Caucasian, though it has been a thoroughfare from the Caucasian to the Negro."107 Contemporary scholars have likewise taken at face value this rule of "hypodescent"- that "the offspring of a Black and a white is Black"108 and the law's function in enforcing it. ${ }^{109}$

Historians have not fully explored the idea that if the white South's racial extremism forced some mulattoes to be black, it pushed others to be white. ${ }^{110}$ People living in the post-Reconstruction era had a keener sense of this possibility. ${ }^{111}$ The prevalence of "passing for white" bedeviled radical racists, and the issue provided a moment of irony for their critics. In an open letter to the racist novelist Thomas Dixon, Howard University Professor Kelly Miller wrote:

[D]o you know, Mr. Dixon, that you are probably the foremost promoter of amalgamation between the two oceans? Wherever you narrow the scope of the Negro by preaching the doctrine of hate you drive thousands of persons of lighter hue over to the white race, carrying more or less Negro blood in their train. ... Hundreds of the composite progeny are daily crossing the color line and carrying as much of the despised blood as an albicant skin can

105. WILliamSON, supra note 104, at 74; see also Amold R. Hirsch, Simply a Matter of Black and White: The Transformation of Race and Politics in Twentieth-Century New Orleans, in CREOLE NEW ORLEANS: RACE AND AMERICANIZATION 262, 265 (Amold R. Hirsch \& Joseph Logsdon eds., 1992) ("The uncertainty, danger, and fundamental unpleasantness of interracial contact in the age of segregation led many blacks to turn inward, to seek solace and security within their own number.").

106. FREDRICKSON, supra note 39 , at $277-79$.

107. STEPHENSON, supra note 28 , at 19.

108. Gotanda, supra note 22, at 24; see also MARVIN HARRIS, PATTERNS OF RACE IN THE AMERICAS 37, 56 (1964).

109. See, e.g., Paul Finkelman, The Crime of Color, 67 TUL. L. REV. 2063, 2109-11 (1993); Carrie Lynn H. Okizaki, Note, "What Are You?": Hapa-Girl and Multiracial Identity, 71 U. COLO. L. REV. 463, 473-75 (2000); Wright, supra note 42, at 524-25.

110. Although Joel Williamson noted that racial extremism "raised . . . difficulties around the central problem of "invisible blackness," he places this observation outside his narrative about the ossification of the black-white racial paradigm and the accompanying (self-)identification of mulattoes with blacks. WILLIAMSON, supra note 104 , at $93,98-100$.

111. See, e.g., CAESAR A.A.P. TAYLOR, THE CONFLICT AND COMMINGling of THE RACES 95 (1913) (recounting several instances of passing that "all point very ominously to the possibility and feasible of unwitting and unwilling amalgamation of races in this country"). 
conceal without betrayal. ... I personally know, or know of, fifty cases of transition in the city of Washington. ${ }^{12}$

The African-American press described people who were white by "simply... keep[ing] their lips sealed," "13 and Ray Stannard Baker discussed various instances of "cross[ing] the line," including the case of Alex Manly, the activist newspaper editor who fled Wilmington, North Carolina, after the 1898 riots and later settled in Philadelphia. After taking several good jobs by passing for white, Manly decided to live openly with his family and settled for work as a janitor. ${ }^{114}$ Literary treatments of passing also abounded, from Chesnutt's The House Behind the Cedars to The Autobiography of an Ex-Coloured Man, James Weldon Johnson's 1912 novel about passing's psychological toll, published anonymously and widely believed at the time to be nonfiction. ${ }^{115}$

More intriguing than passing is the awareness that crossing the color line could be unconscious, unintentional, or simply not fraught with the stresses assumed to be incident to passing: abandoning one's family, betraying one's heritage, and being found out. ${ }^{116}$ If the passer lived with anxiety, his or her children often did not. In the ambiguous world of turnof-the-century Louisiana, it was not uncommon for people to have little idea of their racial ancestry, a situation immortalized in Kate Chopin's short story, Desiree's Baby, in which a man rejects his wife after the birth of a dark-skinned baby, only to find out that he is the one who "belongs to the race that is cursed with the brand of slavery." unique to Louisiana. As a young man in Reconstruction-era North Carolina, Chesnutt encountered people of mixed race whose children were "wholly unaware of their origin." 118 One such woman "married a white man and reared in a neighboring county a family of white children, who, in all

112. KelLy MILLER, As to the Leopard's Spots: An Open Letter to Thomas Dixon, Jr., in RACE ADJUSTMENT: ESSAYS ON THE NEGRO IN AMERICA 28, 48-49 (1908).

113. Willard B. GATEWOOD, ARISTOCRATS OF COLOR: THE BLACK ELITE, 1880-1920, at 175 (1993) (citing Daniel Murray, Color Problem in the United States, 7 COLORED AM. MAG. 719 (1904)).

114. BAKER, supra note 70, at 160-61, 163-64; see also WILLIAMSON, supra note 104, at 100-03 (describing "daytime" and full-time passing).

115. See Werner Sollors, NeITHER BLACK NOR WhITE yet Both: THEMATIC EXPLORATIONS OF INTERRACIAL LITERATURE 264-65, 504 n.91 (1997).

116. See Harris, supra note 22, at 1744 ("Self-determination of identity was not a right for all people, but a privilege accorded on the basis of race. The effect of protecting whiteness at law was to devalue those who were not white by coercing them to deny their identity in order to survive.").

117. KATE ChOPIN, Desiree's Baby, in THE STORM AND OTHER STORJES WTTH THE AWAKENING 111, 116 (Per Seyersted ed., 1974). In Louisiana, many people socially recognized as black "simply did not know whether they were white or black. Their African origins were lost to certain memory, and they were left only with lingering doubts. ... [A]t least three politicians in Reconstruction New Orleans ... were taken as Negroes but yet had no certain knowledge of their Negro ancestry." WILLIAMSON, supra note 104, at 98 (citing David C. Rankin, The Origins of Black Leadership in New Orleans During Reconstruction, 40 J. S. HIST. 422 (1974)).

118. CHESNUTT, supra note 103, at 127. 
probability, were as active as any one else in the recent ferocious red-shirt campaign to disfranchise the Negroes." 119

\section{Enter the Law}

The law is responsible for producing some of the few records of, in Chesnutt's words, "the stream of dark blood [that] has insinuated itself into the veins of the dominant, or, ... the 'domineering' race."120 Chesnutt imagined lawyers as the keepers of the white South's racial secrets; in The House Behind the Cedars, the character of Judge Straight occupied an enlightened position by virtue of his profession:

Certain old decisions with which he was familiar; old scandals that had crept along obscure channels; old facts that had come to the knowledge of an old practitioner, who held in the hollow of his hand the honor of more than one family, made him know that there was dark blood among the white people - not a great deal, and that very much diluted, and, so long as it was sedulously concealed or vigorously denied, or lost in the mists of tradition, or ascribed to a foreign or an aboriginal strain, having no perceptible effect upon the racial type. ${ }^{121}$

Albion Tourgée, a judge during Reconstruction in North Carolina, author of several novels about race, and later counsel for Homer Plessy in Plessy $v$. Ferguson, was reputed to have known "at least a thousand instances of white persons known or suspected to possess a strain of Negro blood."122 In drawing statutory color lines, legislators occasionally showed some consciousness of the effects of their acts. During the 1895 South Carolina Constitutional Convention, Congressman George Dionysus Tillman, the sixty-nine-year-old brother of "Pitchfork Ben," argued strenuously against a proposal to prohibit marriage between whites and people who had "any" black ancestry. Such a provision would have affected several respectable families in his congressional district that had provided soldiers for the Confederacy, Tillman said, going on to claim that "there was not one pureblooded Caucasian on the floor of the convention." The convention adopted a one-eighth rule. ${ }^{123}$

119. Id.

120. Id. at 126 .

121. CHESNUTT, supra note 87 , at 117-18.

122. CHESNUTT, supra note 103 , at 126,131 n.3.

123. GEORge Brown TINDALL, SOUTH CAROLINA NEGROES 1877-1900, at 299 (1952); see also STEPHEN KANTROWITZ, BEN TILLMAN AND THE RECONSTRUCTION OF WHITE SUPREMACY 239-40 (2000) (describing the floor debate between George Tillman and George Johnstone, who supported a one-drop rule). Describing the early national period, historian James Hugo Johnston 
In court, the secrets held in the hollows of lawyers' hands saw the light of day, as cases straddling the color line told numerous stories about the acceptance and absorption of mixed-race people into the white world. Although scholars have explicated the complex treatments of race in antebellum trials ${ }^{124}$ and twentieth-century naturalization hearings, ${ }^{125}$ the color-line cases of the post-Reconstruction era provide a subtle and virtually unheard counterpoint to the din of racial paranoia.

Spencer $v$. Looney provides a tantalizing peek at a secret history of the color line. Plaintiff's counsel noted that " $[t]$ he people of Johnson County [Kentucky] have for many years boasted and felt proud of the fact that they had a white county composed of white citizens." ${ }^{26}$ The plaintiff presented evidence that his family had always attended white schools and churches, and, in fact, " $[t]$ here were no other churches or schools here only what termed themselves white." ${ }^{27}$ Yet a more colorful picture of the area emerges from the hundred-page record of the trial, along the lines of what seventy-five-year-old James H. Spradlin, a retired Paintsville businessman, told the court about his home county: "It has a right smart sprinkle of African and Indian blood, or that is my opinion." 128

Leaving aside the precise demographics of the Virginia-Kentucky borderland, the evidence in Spencer $v$. Looney offers a portrait of the plaintiff's grandfather that at the very least complicates assumptions about how people in that area lived their lives. Jordan Spencer, Sr., may well have been, in the words of "loafer [and] retired physician" I.R. Turner, "neither black nor white." 129 The evidence was enough to convince a jury to decide the libel case in favor of the defendant, Looney. According to the plaintiff's first cousin "on both sides," "[i]t is generally talked over the country that [the Spencers] had Negro blood in them," "130 and many witnesses said that people occasionally called Jordan Spencer "a negro or darkey on account of being mad at him." ${ }^{\prime 31}$ Spencer had for decades been a subject for chitchat,

suggests that similar concems may explain the intent behind prior statutory definitions of race that avoided the one-drop rule:

[L]awmakers ... feared that a declaration to the effect that the possession of any Negro ancestry, however remote, made a man a mulatto might bring embarrassment on certain supposedly white citizens. No doubt, it was also believed that it would be exceedingly difficult, if not impossible, to enforce a more drastic law.

JOHNSTON, supra note 102, at 193-94.

124. See HODES, supra note 64; Gross, supra note 22.

125. See HANEY LÓPEZ, supra note 38; Braman, supra note 22; Tehranian, supra note 37.

126. Spencer Transcript, supra note 6 , at 145.

127. Id. at 60 (testimony of John W. Hom).

128. $I d$. at 145 (testimony of James H. Spradlin).

129. Id. at 141 (testimony of I.R. Tumer).

130. Id. at 110 (testimony of John A. Looney).

131. Id. at 91 (testimony of A.L. Rice); see also id. at 70 (testimony of William H. Johnson) ("I guess they called him a negro just like other white men, but I never heard no person call him that in reasonable conversation, of course when they got into difficulties, and were mad, they called him a negro."). 
whether about his mysterious origins outside of Johnson County or about his "paint[ed]" hair, which, according to one witness, made the sweat on his temples run red. ${ }^{132}$ John D. Preston, a retired businessman, recalled that Spencer associated with a group of families assumed to have "some Indian blood in them." ${ }^{.13}$ After a series of leading questions by defense counsel, Preston also testified that he had heard that Spencer "was once a slave, that is my recollection, I wouldn't be positive, and that he bought his freedom." 134

Whether or not some of the more piquant details are true, the evidence portrayed a man who lived for more than fifty years as an active member of a small white community. Race consciousness meant little more than idle gossip and the occasional insult by people who "had dealings with [Spencer], met him in court and on the muster ground before the war" 135 people who worked with Spencer, ate with him, bunked with him, prayed with him, and schooled their children with his. Although he had married "as white a woman as you find anywhere," ${ }^{136}$ none of the witnesses expressed any concern about miscegenation. The terror and violence of the postReconstruction South did not know Jordan Spencer. Even the most hostile defense witnesses viewed him not as a menace, but rather as an immigrant to be assimilated. "I was always in sympathy with the man," said J.W. Castle, a Paintsville furniture dealer, "because he tried to be a good man, and tried to avoid looking like a darkey, and because he wanted to raise himself up instead of lowering himself." 137

Before his feud with Looney, George Spencer had lived a life similar to that of his grandfather, one of widespread acceptance toward him, the local woman he married, and their six children. Although the plaintiff denied knowing that his family had a reputation for being "a little bit negro," 138 the evidence even presents the possibility that he wore his background lightly. One of his friends testified that while "on a drunk" together, Spencer said that his family was "mixed blooded, he said he had Negro blood in him, but he didn't object as it made him hardy." ${ }^{39}$ There was no reason to object,

132. Id. at 137 (testimony of Wallace Lemasters); see also id. at 119 (testimony of John D. Preston) ("Q. About how old was he when he came to this county? A. Thirty-five or forty. Q. You never knew him before he came here? A. No, sir. Q. Never knew his father? A. No, sir. Q. Never knew his mother? A. No, sir. Q. Never knew any of his people? A. No, sir."); id. at 131 (testimony of J.W. Castle) ("I have heard him discussed several times, right after the war, and we always concluded that he was a little bit negro?").

133. Id. at 124 (testimony of John D. Preston).

134. Id. at 117.

135. Id. at 139 (testimony of $\mathrm{J}: \mathrm{W}$. Walker).

136. Id. at 64 (testimony of John W. Horn).

137. Id. at 127 (testimony of J.W. Castle).

138. Id. at 131 .

139. Id. at 113 (testimony of Albert Stevenson). Spencer denied that this conversation ever took place. $I d$. at 97 (testimony of George Spencer). 
even in 1911 in southwestern Virginia, until Looney forced him to consider the legal consequences of racial difference.

Spencer $v$. Looney is hardly the only window onto a world where race did not relentlessly determine the course of people's lives. In Ferrall $v$. Ferrall, heard by the North Carolina Supreme Court in 1910, a man tried to annul his marriage on the ground that he had unwittingly married a black woman. ${ }^{140}$ When the plaintiff and defendant were courting, it was widely rumored that "there was a strain of Indian or Portuguese blood in defendant's veins." public objection. When he sued for annulment several years later, the trial did not arouse any public comment. His ex-wife and daughter stayed in the area, and if their habit of dipping snuff was frowned upon, they nevertheless were regarded as white people. ${ }^{142}$ These stories lie beneath the surface of any number of cases. ${ }^{143}$ Routine or trivial enough not to attract attention from yellow journalists or white mobs, color-line trials regularly appeared on judicial dockets during the post-Reconstruction era, exposing to the courts the African heritage of many white Southerners-and the widespread acceptance of racial ambiguity in white communities.

\section{Preserving a Porous Color Line}

Confronting obvious contradictions between the prevailing racial hysteria and the realities of everyday life, Southern courts did not naively ignore the artificiality of the color line, nor did they show some awareness of it, only to disregard it in the blind service of maintaining white

140. 69 S.E. 60 (N.C. 1910).

141. Id.

142. Daniel Jacob Sharfstein, In Search of the Color Line: Ferrall v. Ferrall and the Struggle To Define Race in the Turn-of-the-Century American South 7 (1994) (unpublished A.B. thesis, Harvard University) (on file with the Harvard University Library).

143. See, e.g., Lee v. New Orleans Great N. R.R. Co., 51 So. 182 (La. 1910) (affirming the dismissal of a suit brought after a railway conductor forced two teenage girls to ride in the Jim Crow car, where witnesses and property deeds suggested that the plaintiff's grandfather was of mixed blood); Hare v. Bd. of Educ., 18 S.E. 55 (N.C. 1893) (finding no error in the exclusion of a child from the local public schools); Hopkins v. Bowers, 16 S.E. 1 (N.C. 1892); Bell v. State, 25 S.W. 769 (Tex. Crim. App. 1894); see also BAKER, supra note 70, at 152-53 (discussing an inheritance suit in Tipton County, Tennessee, in which a jury found in favor of a cotton planter's daughter alleged to be black); DOMíNGUEZ, supra note 39, at xiv, 23-89 (discussing numerous cases of "conscious manipulation of identity throughout the history of Louisiana"); FISHKIN, supra note 95, at 126 (citing a 1910 "Negro Blood Divorce Case" in Illinois); SOLLORS, supra note 115, at 419-20 n.87, $435 \mathrm{n} .80$ (describing the Rhinelander case of 1924-1925, an interracial marriage annulment case involving the heir of one of New York City's richest families and covered exhaustively by the press); STEPHENSON, supra note 28 , at $17,25 \mathrm{nn} .31-33$ (citing McMillan v. Sch. Comm'n, 12 S.E. 330 (N.C. 1890)); Gross, supra note 22, at 138 n.100, 142 n.122, $179-80$ (citing several post-Civil War cases); Calvin Trillin, Black or White, NEW YORKER, Apr. 14, 1986, at 62 (describing the case of Susie Guillory Phipps, who sued the state of Louisiana in 1983 to change the racial designation on her birth certificate from "colored" to "white"). 
supremacy. ${ }^{144}$ Rather, the law of race at the turn of the century seemed to preserve the status quo and all its contradictions. With unique access to the South's racial secrets, courts often worked to discourage anyone who would actively unearth them. One historian has documented how immediately after the Civil War, technical pleading requirements often protected freedmen from prosecution by whites. ${ }^{145}$ In the post-Reconstruction era, the law protected white people from themselves.

A foundational case in this regard is Plessy v. Ferguson. ${ }^{146}$ The plaintiff, Homer Plessy, was not discernibly of African descent and argued that the Louisiana statute deprived him of property-a reputation for being white - without due process of law. ${ }^{147}$ On the issue of Plessy's race, the Court discussed how the definitions of blackness varied from state to state yet declined to set a single standard. ${ }^{148}$ As described in Section I.A of this Essay, scholars have identified this discussion, found in the final paragraph of the majority opinion, as providing a key to understanding the Court's awareness of the arbitrary nature of the color line. But another portion of the case tells a more significant story about the history of race. While upholding the constitutionality of segregation, the Court did not decide the question of whether Louisiana could indemnify railroads from lawsuits seeking "damages for a refusal to receive [a passenger] into the coach in which he properly belongs .... Indeed, we understand it to be conceded by the state's attorney that such part of the act as exempts from liability the railway company and its officers is unconstitutional." 49 If a white passenger is sent to a black car, "he may have his action for damages against the company for being deprived of his so called property." 150

This affirmation of common-law rights did not merely show, as one scholar put it, a "chronic refusal to dismantle the structure of white supremacy." 151 While the effect of Plessy was to give "[t]he conductor of a

144. See Braman, supra note 22, at 1399-400 (noting "evidence of the Court's recognition of the sociopolitical nature of racial classifications ... in even [the] most trenchant of discriminatory findings"); Haney López, supra note 20, at 4-5 (" $[I] n$ the last two centuries our conception of race has not progressed much beyond [a] primitive view [of race] . ...").

145. See Christopher Waldrep, Substituting Law for the Lash: Emancipation and Legal Formalism in a Mississippi County Court, 82 J. AM. HIST. 1425, 1425, 1449, 1451 (1996); id. at 1427 ("Once in the hands of local legal professionals, even highly discriminatory legislative enactments became subject to the logic of local legal culture. Judges and lawyers in the Black Code era granted Black defendants common-law safeguards antebellum whites had carefully denied almost all slave defendants.").

146. Plessy v. Ferguson, 163 U.S. 537 (1896).

147. See id. at 549. For thorough discussions of this aspect of Plessy's case, see Braman, supra note 22, at 1393-400; and Harris, supra note 22, at 1746-50.

148. Plessy, 163 U.S. at 552.

149. Id. at 549 .

150. Id.

151. Harris, supra note 22, at 1750. 
train ... the power of an autocrat," ${ }^{152}$ the availability of damages suits inhibited overzealous enforcement of laws mandating segregation. Plessy $v$. Ferguson may have elevated racial separation to the level of constitutional truth, but it also encouraged white Southerners creating their new society to leave some stones unturned.

Almost immediately after Plessy, Chesnutt-who had a very light complexion-had the opportunity to test the case's effect. Riding a train into Virginia, Chesnutt sat in a white car and engaged in mischievous colloquy with the conductor. He asked the conductor about the newly implemented "Jim Crow car system," and the conductor said he had to enforce the law vigorously: "Personally I don't mean to take any chances: I've been hauled up in court once, or threatened with it, for not enforcing the law. I'd put a white man out of the colored car as quick as I'd put a nigger out of this one." ${ }^{\prime 153}$ Chesnutt took the issue an innocent step further: "'Do you ever,' I asked, 'have any difficulty about classifying people who are very near the line?' . . 'What do you do in a case of that kind?"” "I give the passenger the benefit of the doubt," the conductor answered. ${ }^{154}$ Chesnutt recounted this anecdote in a 1901 essay called The White and the Black, and he followed it with the story of a conductor in North Carolina who identified a woman in a white car "as colored, and upon whom he pounced with the zeal of a newly promoted man." 155 The day after she was assigned to the black car, a suit was brought against the railroad seeking $\$ 25,000$ damages. ${ }^{156}$ The ready availability of such causes of action ${ }^{157}$ meant that

152. Chesnutt, supra note 77, at 141 . In Chesnutt's words, the train conductor "nods his Jovelike head, corrugates his high Caucasian brow and the Negro seldom argues, because there is no use in doing so." Id.

153. Id.

154. Id.

155. Id. at 142 .

156. Id.

157. See. e.g., Wolfe v. Ga. Ry. \& Elec. Co., 58 S.E. 899, 901 (Ga. Ct. App. 1907) ("In no case where a passenger is mistreated can the fact that the servant of the company was carrying out the provisions of the Penal Code be used as a defense ...."); May v. Shreveport Traction Co., 53 So. 671 (La. 1910) (holding a streetcar company liable when a conductor gestured that a passenger should sit in the seats reserved for blacks); Lee v. New Orleans Great N. R.R. Co., 51 So. 182, 184 (La. 1910) (affirming the dismissal of a suit brought after a railway conductor forced two teenage girls to ride in the Jim Crow car, where it was conceded that the maternal grandfather of the girls was of mixed blood, and witnesses suggested he was of African descent); see also BAKER, supra note 70, at 151-52 (discussing a lawsuit against the Norfolk \& Western Railroad brought by a woman erroncously forced to ride in a Jim Crow car in Norfolk, Virginia). Some courts, however, were unwilling to recognize such causes of action. In Southern Railway Co.v. Thurman, the Kentucky Supreme Court held that

[w] hat race a person belongs to cannot always be determined infallibly from appearances, and mistakes must inevitably be made. When a mistake is made, the carrier is not liable in damages simply because a white person was taken for a negro, or vice versa. It is not a legal injury for a white person to be taken for a negro. It was not contemplated by the statute that the carrier should be an insurer as to the race of its passengers. 
conductors learned to stay far from the color line; the Jim Crow era, in many parts of the South, was also the era of the benefit of the doubt.

Railroads were not the only setting for cases in which courts discouraged whites from investigating and exposing the racial heritage of their family, friends, neighbors, and enemies. Spencer $v$. Looney ${ }^{158}$ arose from the expulsion of the plaintiff's child from a white school. On appeal to the Virginia Supreme Court, the case hinged on whether the defendant had the privilege, "if not the duty," to inform school authorities that the plaintiff's son was not white. ${ }^{159}$ In his brief to the court, Looney argued that even if his allegations were defamatory and false, his actions should be privileged because the public's interest in the segregation of schools outweighed the plaintiff's reputational interests:

We take it that it is ... a matter of vital importance to the Commonwealth, to preserve the racial integrity and superiority of the white man.... Few things would militate more against this policy and tend more toward social equality and the amalgamation of the races than to educate them together... . Now how can such policy be properly carried into effect ... if the patrons of the school be not allowed, without fear of slander suits, to protest in and among themselves, and to the tribunal created by law to pass upon such questions, against pupils, who they do not consider under the laws entitled so to do, attending the same school attended by their children. ${ }^{160}$

The court did not rate the segregation of schools as a policy issue urgent enough to warrant an absolute privilege for slanderous remarks. Rather, a qualified privilege would attach, which would be defeated by a showing that the slander was motivated by malice. ${ }^{161}$ Unfortunately for Looney, the court inferred malice from the "profane, uncalled for, and violent language"162 that Looney used when he called the Spencers "God damned negroes," $" 163$ from the fact that the two families had been friendly until the

90 S.W. 240, 241 (Ky. 1906); see also BARBARA YOUNG WELKE, RECASTING AMERICAN LIBERTY: GENDER, RACE, LAW, AND THE RAILROAD REVOLUTION, 1865-1920, at 357-58 (2001) (describing the split among Southern states over indemnifying railroads for mistaken racial identification). The emergence of railroads as a primary locus for suits revolving around racial identity faintly echoes a history of intense litigation about segregation in public transportation throughout the latter half of the nineteenth century. See generally Barbara Y. Welke, When All the Women Were White, and All the Blacks Were Men: Gender, Class, Race, and the Road to Plessy, 1855-1914, 13 LAW \& HIST. REV. 261 (1995) (describing a series of cases challenging segregation on common carriers before statutory Jim Crow).

158. 82 S.E. 745 (Va. 1914).

159. Id. at 746 .

160. Spencer Appellee Brief, supra note 8, at 13-14.

161. Spencer, 82 S.E. at 747 .

162. Id.

163. Id. at 746 . 
defendant's brother was murdered, and from the ferocity with which Looney waged his feud: paying the expenses for school board members on two investigative forays into Johnson County and calling a board meeting to expel the child without notice to Spencer. ${ }^{164}$

The test for qualified privilege was not only strictly enforced-the court ignored the defendant's pleas to disregard his profanity as mere verbal tics of an inveterate foulmouth ${ }^{165}$-but it was also imbued with considerations of past reputation and the availability of due process. By inferring malice, in part, from Looney's zealous investigation of the race of people reputed to be white, the court made it difficult for anyone to raise questions about racial identity without fear of legal action. No matter how compelling it was to "preserve the racial integrity and superiority of the white man," the court had some understanding that a judgment for Looney would portend a bleak future for the white South—the possibility that petty feuds would increasingly take the form of racialized witch hunts, that government authorities would reflexively err on the side of racial paranoia, and that a good number of allegations might be borne out with the proper investigation. The Virginia Supreme Court refused to allow the policing of the color line to become a casual enterprise.

Likewise, the North Carolina Supreme Court in Ferrall v. Ferrall refused to make it easy for white husbands to annul their marriages on the grounds that their wives were discovered to be black. ${ }^{166}$ North Carolina's antimiscegenation statute voided marriages between a white and "a person of negro or Indian blood to the third generation inclusive"167 - that is, someone one-eighth black or Indian. At issue in Ferrall was how this oneeighth rule would be construed where the defendant had one greatgrandfather of partial African descent. The court held that she was legally white unless her great-grandfather was a "full negro," a "negro of pure African blood." 168 Even though the state legislature had recently taken a hard line on race with a statute mandating that "no child with negro blood in its veins, however remote the strain, shall attend a school for the white race," 169 the court applied what was essentially a reverse one-drop rule for Susie Patterson Ferrall—one drop of white blood in her great-grandfather made her white.

164. Id. at 747-48.

165. Looney did not attempt to deny Spencer's version of the facts, which "ha[d] the term, 'God damned negroes,' coming twelve times from the lips of the Appellee." Spencer Appellee Brief, supra note 8, at 9 . Rather, Looney argued that "a man may be both coarse and profane and yet not have malice. The gist and substance of the charge in this case was the use of the word negro ... . The adjectives, prefixed to the use of the word were of small importance." Id.

166. 69 S.E. 60 (N.C. 1910).

167. Id. at 61 .

168. Id.

169. Id. at 62 . 
Although the majority opinion justified its holding with a formalistic nod to a series of antebellum cases, a concurrence by Chief Justice Clark suggested a more immediate ideological impetus behind the ruling. Frank Ferrall had abused his wife and daughter. "If he could show fault in her conduct in any way," Clark wrote, "it is to be presumed that in these days of easy divorce he would have sued on that ground. His divorced wife might ... have been still entitled to alimony and dower."170 Although the color line had long been a legal shield for the sexual exploitation of black women by white men, ${ }^{171}$ it now threatened to become a means for white men to impoverish their white wives and "bastardize [their] own innocent children."172 Considering that prospect, Clark declared that questions about individual racial identity often did not belong in the public sphere:

If, indeed, the plaintiff had discovered any minute strain of colored origin after the youth of his wife has been worn away for his pleasure and in his service, justice and generosity dictated that he keep to himself that of which the public was unaware, or, if the knowledge had become public and was disagreeable, the plaintiff, if possessed of any sentiment of manhood, would have shielded his wife and children by removing to another locality or to a state where the fact, if known, would not be deemed a stigma. ${ }^{173}$

The hysteria over "the infamy of social degradation from the slightest infusion of Negro blood" had broad potential to destabilize a white society that had long included numerous people of $A$ frican descent. ${ }^{174}$ The North Carolina Supreme Court's strict reading of antimiscegenation laws in Ferrall v. Ferrall ensured - for the sake of white womanhood-that racial secrets stayed behind closed doors.

Even as extreme racism and terrorist violence became the order of the post-Reconstruction era, many whites and blacks retained some idea that

170. Id. (Clark, C.J., concurring).

171. See LITWACK, supra note 62, at 343-48 (noting the "deep historical roots" of the sexual exploitation of black women by white men and that such abuse continued unpunished "long after the Civil War"). The Wilmington, North Carolina, riots of 1898 began in response to editorials by black newspaper editor Alex Manly on the subject of hysteria over the dangers of black rapists. Addressing white women, Manly wrote, "Tell your men that it is no worse for a black man to be intimate with a white woman than for a white man to be intimate with a colored woman." Id. at 313.

172. Ferrall, 69 S.E. at 62 (Clark, C.J., concurring).

173. $I d$.

174. Id. Randall Kennedy discusses Ferrall as a result likely dictated by the judges' "empathy" for, and "generosity" toward, an abandoned and abused wife. Randall Kennedy, The Enforcement of Anti-Miscegenation Laws, in INTERRACIALISM: BLACK-WHITE INTERMARRIAGE IN AMERICAN HISTORY, LITERATURE, AND LAW 140, 158-60 (Werner Sollers ed., 2000). While this is undoubtedly true, the holding in Ferrall must also be understood more broadly: A decision in the husband's favor would not only have allowed Frank Ferrall to impoverish his wife and child, but it would also have opened the door to thousands of other men to do the same thing to their families. 
the color line was artificial or imperfectly drawn. If such ideas were not easy to express in a society that refused to tolerate dissent, the realities of everyday life-revealed in cases such as Spencer and Ferrall-showed what Charles Chesnutt had theorized: that many white Southerners had African ancestry and that white communities could function peacefully with that knowledge, whether as family secrets or idle gossip. More than most public institutions, the courts confronted these realities and generated a body of law that encouraged suits for loss of white racial reputation and discouraged efforts to investigate and uncover individuals' racial backgrounds. The Southern courts refused to let a white public hungry for racial purity devour its private self.

\section{E. The Social Constructivism of Racists}

Faced with a law of the color line that protected the status quo, radical segregationists developed critiques that would be instantly recognizable in today's histories of race: They traded on the idea that judicially crafted rules were mere social constructions. These arguments assumed a number of different forms, but are united by a common perception that a gap existed between formalistic rules of law and the reality of life in the South.

On one level, segregationists attempted to evade unfriendly legal doctrines with formalisms of their own. In libel and slander cases, for example, antebellum courts had held that calling a white person black was actionable per se, recognizing that the institution of slavery threatened grave consequences for even the idlest of insults. ${ }^{175}$ After the Civil War, defendants in several cases, including Spencer $v$. Looney, attempted to argue that such a doctrine was obsolete because "[e]ver since the adoption of the 13th and 14th amendments ... the negro has practically been declared peer to the white man of the purest and best Caucasion [sic], Anglo-Saxon or Norman blood."176 Because the races were equal, defendants argued, "[h]ow can the law of the land... say that it is insulting, scandalous and defamatory to call anyone a negro?"177 Courts in Georgia, South Carolina, and Virginia rejected those arguments, relying on the familiar distinction made at the time between "political equality" and "social equality"- even though the Reconstruction Amendments gave blacks a measure of legal equality, blackness remained a social stigma,

175. This cause of action dates back to Eden v. Legare, 1 S.C.L. (1 Bay) 169 (1791) (holding it slanderous per se to call a white man a mulatto).

176. Petition of Plaintiff in Error at 44, Spencer v. Looney, 82 S.E. 745 (Va. 1914) (No. 2012) (reprinting the defendant's demurrer); see also Flood v. News \& Courier Co., 50 S.E. 637, 638 (S.C. 1905) (quoting the demurrer of a newspaper sued for printing a news item that erroneously identified an accident victim as "colored").

177. Petition of Plaintiff in Error, supra note 176, at 45 (reprinting the defendant's demurrer). 
keeping alive the cause of action for defamation. ${ }^{178}$ If defendants' argument offered a more faithful reading of the Constitution, it nevertheless contrasted - at least in Looney's case-with their actual belief in white supremacy. And Looney admitted as much. Whatever can be said about him, he knew that his argument was "based upon a legal fiction." 179

On another level, some segregationist arguments attacked judicial definitions of the color line as themselves legal fictions. Alfred Holt Stone, a Mississippi planter, former slaveholder, and gentleman race theorist, ${ }^{180}$ argued that categorizing mulattoes as blacks allowed Northerners to point to mixed-race people such as Chesnutt as examples of black intellectual achievement, thus undermining the white South's "more or less definite convictions on the question of Negro inferiority."181 "The mulatto is not a Negro," Stone wrote in 1908, "and neither written nor social law can make him one." 182 To preserve white supremacy, Stone advocated the introduction of a mixed-race designation, like the one then in use in South Africa. ${ }^{183}$

In the courtroom, a more hard-line argument took shape. Take, for example, Ferrall v. Ferrall, the annulment case. The plaintiff's brief to the court, written by a lawyer recognized as one of the best in the state, ${ }^{184}$ stated

178. See Wolfe v. Ga. Ry. \& Elec. Co., 58 S.E. 899, 901 (Ga. Ct. App. 1907) ("We take judicial notice of an intrinsic difference between the two races... Notice of this difference does not imply legal discrimination against either, and for that reason cannot in any sense, impugn or oppose the Fourteenth and Fifteenth amendments to the Constitution of the United States ...."); Flood, 50 S.E. at 640 ("Now, it must be apparent from consulting the texts of these amendments that there is not the slightest reference to the social conditions of the two races, and nothing can be imported into these amendments to give any such effect. All take pleasure in bowing to the authority of the United States in regard to these three amendments, but we would be very far from admitting that the social distinction subsisting between the two races has been in any way affected."); Spencer, 82 S.E. at 747 (citing Flood, 50 S.E. at 637); cf. Plessy v. Ferguson, 163 U.S. 537,544 (1896) ("The object of the [Fourteenth] amendment was undoubtedly to enforce the absolute equality of the two races before the law, but in the nature of things it could not have been intended to abolish distinctions based upon color, or to enforce social, as distinguished from political equality, or a commingling of the two races upon terms unsatisfactory to either.").

179. Petition of Plaintiff in Error, supra note 176, at 45 (reprinting the defendant's demurrer).

180. AYERS, supra note 62, at 195; LITWACK, supra note 62, at 219.

181. Alfred HOLT STONE, STUDIES IN THE AMERICAN RACE PROBLEM 398 (1908); see also id. at 41-42. On Chesnutt, Stone wrote:

Nobody thinks of using [Alexandre Dumas] as a demonstration of Negro capacity, simply because one of his ancestors happened to be a mulatto of Martinique. Yet that is just what [William Dean Howells] docs in the case of [Chesnutt] who has less Negro blood in his veins than Dumas had in his. Here is a man who might defy an ethnologist to say that he had a drop of Negro blood; yet because an arbitrary social custom classes him as a Negro (and, by the way, he does not live in the South), thousands read his books, or listen to his spoken words, or engage him in social intercourse-and thereby form mature and well considered judgments as to the character and possibilitiesabove all, the possibilities - of the masses who confront the Southern white man.

Id. at $41-42$.

182. Id. at 398 .

183. Id. at 407.

184. See Sharfstein, supra note 142 , at 6 . 
outright that North Carolina's antimiscegenation law should be read to prohibit marriages between whites and anyone who is not "altogether free of the African taint": "It may seem a hard verdict for the negro; but it is the only policy that is sound." 185 This argument was a stretch, considering, as was noted in the previous Section, that North Carolina courts had strictly read the statute's one-eighth rule to mean three generations removed from a "pure African" ancestor. ${ }^{186}$ Nevertheless, Frank Ferrall pressed his case for the most extreme, biologically driven notion of race by arguing that the court's own biological assumptions about race were false. "[T]he word 'negro' ... cannot mean a pure-blooded African," Ferrall's brief argued. "There have not been any in the State in a century..." Rather, the statutory prohibition of marriage between whites and people "of negro descent to the third generation[] must have meant the descendant of any person whose social status, associations and daily living stamped him as being a negro." 187 The less mathematically precise the definition of blackness-Ferrall sought to set the line at anyone "who fixes his own status, or has it fixed for him, by association with the negro race"-the more people would be designated legally black. ${ }^{188}$ In Ferrall v. Ferrall, reputational and performative evidence of race did not merely exist alongside or compete with the biological notions of race that purportedly necessitated the one-drop rule, ${ }^{189}$ rather, such evidence was invoked to assure the triumph of one-drop extremism. Although the state supreme court was not ultimately convinced, this argument did persuade the trial judge to rule for the plaintiff notwithstanding a jury verdict in favor of his wife. The social construction of race threatened to replace fractional definitions of race with an even more oppressive regime.

\section{CONCLUSiON: GetTING PERSONAL}

Within ten years of Spencer $v$. Looney, the hard-line politics of the era caught up with the court decisions that had held them at bay. In 1924, the Virginia legislature passed An Act To Preserve Racial Integrity, which defined whiteness as having "no trace whatsoever of blood other than Caucasian."

185. Ferrall Plaintiff's Brief, supra note 95 , at 2.

186. See supra text accompanying notes $166-169$.

187. Ferrall Plaintiff's Brief, supra note 95 , at 3.

188. Id.

189. Cf. Gross, supra note 22, at $156-57$ (describing how performative evidence in trials in the $1850 \mathrm{~s}$ and $1860 \mathrm{~s}$ "sometimes serv[ed] as a counterweight to 'scientific' evidence" and "sometimes [served] in conjunction with it").

190. An Act To Preserve Racial Integrity, $1924 \mathrm{Va}$. Acts ch. 371 (held unconstitutional in Loving v. Virginia, 388 U.S. 1 (1967)). An exception was made for people with less than onesixteenth Indian blood, id., owing to the fact that many upper-class Virginians traced their roots 
America" succeeded in doing what the courts would not. The state Bureau of Vital Statistics began an aggressive effort to "properly classify[] [Virginia's] population as to color,"191 and the agency unilaterally altered racial designations on birth, marriage, and death certificates. ${ }^{192}$ After the Louisiana Supreme Court ruled that anyone of traceable African origin was "colored," that state's Bureau of Vital Statistics assumed an equally powerful role in maintaining the racial order. ${ }^{193}$

The shift from courts to bureaucracy as custodians of the color line was profound, in large part because the judicial function was always bounded by messy individual circumstances. Even as the South was awash with racial hysteria and bloodletting, on a case-by-case level there were moments of calm and clear sight about race. Communities could live with the idea that some whites among them had African ancestry. Courts knew that the color line did not perfectly separate blacks and whites and had the occasional insight that making the color line a closer approximation of the racist rhetoric of the day would be a disaster-for whites. Racial inequality undoubtedly corrupted Southern law. Statutes and precedent mattered little where "negro law" prevailed-selective enforcement and sentencing that "rested largely on custom, racial assumptions, the unquestioned authority of whites, and a heavy dose of paternalism. ${ }^{.194}$ Yet in the strange subset of cases about racial determination, many holdings discouraged overzealous policing of the color line. Even if such decisions kept a segregated society's wheels greased, the courts were not acting, as some scholars would have it, in the blind thrall of, or out of unrelenting allegiance to, white supremacy. The reality of everyday lives - the facts of cases, the longstanding acceptance of the Spencers in their Kentucky and Virginia communities, the abuse that Susie Ferrall suffered at the hands of her husband--kept the courts somewhat out of lockstep with the politics of radical segregation.

back to Pocahontas and John Rolfe. Paul A. Lombardo, Miscegenation, Eugenics, and Racism: Historical Footnotes to Loving v. Virginia, 21 U.C. DAVIS L. REV. 421, 434 \& n.60 (1988).

191. J. DAVID SMITH, THE EUGENIC ASSAULt ON AMERICA: SCENES IN RED, WHITE, AND BLACK 61 (1993) (quoting Letter from Walter Ashby Plecker to the Editor of Survey Graphic (Mar. 13, 1925) (on file with the John Powell Collection, Alderman Library, University of Virginia)). Although an early version of the Racial Integrity Act required Virginians to register their race and provide genealogical evidence to the Bureau of Vital Statistics, that provision was made voluntary after supporters of the law expressed reservations. Id. at 59-60.

192. Id. at 65-66; Lombardo, supra note 190, at 447-48 (describing the Bureau's intrusive investigations and its policy of putting notations on the back of birth certificates suspected of being filed under the "incorrect" race); Peter Hardin, "Documentary Genocide": Families' Surnames on Racial Hit List, RICHMOND TIMES DISPATCH, Mar. 5, 2000, at Al.

193. See DOMÍNGUEZ, supra note 39, at 36-37 (describing the Louisiana Bureau's policy of "flagging" birth certificates for further investigation).

194. LITWACK, supra note 62, at 258. 
Segregationists understood this disjuncture and attacked it. ${ }^{195}$ In colorline cases, the adversarial process invited creative critiques of unfriendly precedent, including observations that legal rules were mere social constructions. In many more cases, the assault on the courts took the form of lynchings and terrorist actions. Legislatures tightened definitional statutes, and, at least in Virginia and Louisiana, the color line became for most purposes an administrative matter.

Yet even modern bureaucracy did not wipe out the deeply idiosyncratic nature of racial determination. Far from exhibiting the cold efficiency of the administrative state, the "vital statistics" regimes in Virginia and Louisiana functioned in a personality-driven, even neurotic, fashion, in some ways confirming what courts feared would happen if racial divisions were enforced more strictly. In Virginia, Walter Ashby Plecker, who served as the state registrar of vital statistics from 1912 to 1946, kept "hit lists" of people with suspicious origins and bragged-in 1943-that his records were as thorough as Hitler's genealogies of Jews. ${ }^{196} \mathrm{He}$ cut enough of an odd figure that he was the basis for a character named Dr. Samuel Buggerie in Black No More, a 1931 satire by the Harlem Renaissance novelist George Schuyler. ${ }^{197}$ In Louisiana, Naomi Drake's sixteen-year tenure in charge of vital statistics involved the refusal to issue thousands of birth and death certificates because she felt that the racial identities of the people involved needed additional investigation. By her edict, the entire population of White Castle, Louisiana, was presumed to be "half breeds," and she compiled lists of names that were automatically regarded as suspicious, including Adams, Charles, Landry, and Olsen. ${ }^{198}$

What most legal histories of these issues have omitted--but what must not be forgotten - is that race is, at root, personal. The historian Thomas C. Holt wrote that the study of race is in many ways the study of "everyday life and "everydayness."'199 Cases like Spencer v. Looney, Ferrall v. Ferrall, and even Plessy v. Ferguson show not only that race is situated at a peculiar intersection of large ideas and the minutiae of everyday experience-the place where a person becomes a problem, as W.E.B. Du Bois famously observed ${ }^{200}$ - but also that courts occupy much of that same terrain. Legal materials are essential sources for the history of race, as much

195. Cf. Waldrep, supra note 145 , at $1425,1445-46,1449-51$ (describing white hostility to Reconstruction-era legal process because legal formalism thwarted whites' attempts to use law "as an instrument of their domination over blacks").

196. Lombardo, supra note 190, at 449 n.132; Hardin, supra note 192.

197. SOLLORS, supra note 115 , at 279.

198. At least 4700 birth certificates and 1100 death certificates were held in abeyance between 1960 and 1965. DOMINGUEZ, supra note 39, at 37-45; James O'Byrne, Many Feared Naomi Drake and Powerful Racial Whim, NeW ORLEANS TIMES-PICAYUNE, Aug. 16, 1993, at A7.

199. Holt, supra note 40 , at 7 .

200. DU BoIs, supra note 40 , at 1-2. 
for the ideas that judges generated about the color line as for the insights cases reveal about the lives lived in its shadow. To make sense of either, one must make sense of both. 
世卖*

HeinOnline -- 112 Yale L.J. 1510 2002-2003

Imaged with the Permission of Yale Law Journal 